\title{
Evaluation of improved land use and canopy representation in BEIS v3.61 with biogenic VOC measurements in California
}

\author{
Jesse O. Bash ${ }^{1}$, Kirk R. Baker ${ }^{2}$, and Melinda R. Beaver ${ }^{2}$ \\ ${ }^{1}$ US Environmental Protection Agency, Office of Research and Development, Research Triangle Park, NC, USA \\ ${ }^{2}$ US Environmental Protection Agency, Office of Air Quality Planning and Standards, Research Triangle Park, NC, USA \\ Correspondence to: J. O. Bash (bash.jesse@epa.gov)
}

Received: 12 August 2015 - Published in Geosci. Model Dev. Discuss.: 21 September 2015

Revised: 8 April 2016 - Accepted: 10 May 2016 - Published: 16 June 2016

\begin{abstract}
Biogenic volatile organic compounds (BVOC) participate in reactions that can lead to secondarily formed ozone and particulate matter (PM) impacting air quality and climate. BVOC emissions are important inputs to chemical transport models applied on local to global scales but considerable uncertainty remains in the representation of canopy parameterizations and emission algorithms from different vegetation species. The Biogenic Emission Inventory System (BEIS) has been used to support both scientific and regulatory model assessments for ozone and PM. Here we describe a new version of BEIS which includes updated input vegetation data and canopy model formulation for estimating leaf temperature and vegetation data on estimated BVOC. The Biogenic Emission Landuse Database (BELD) was revised to incorporate land use data from the Moderate Resolution Imaging Spectroradiometer (MODIS) land product and 2006 National Land Cover Database (NLCD) land coverage. Vegetation species data are based on the US Forest Service (USFS) Forest Inventory and Analysis (FIA) version 5.1 for 2002-2013 and US Department of Agriculture (USDA) 2007 census of agriculture data. This update results in generally higher BVOC emissions throughout California compared with the previous version of BEIS. Baseline and updated BVOC emission estimates are used in Community Multiscale Air Quality (CMAQ) Model simulations with $4 \mathrm{~km}$ grid resolution and evaluated with measurements of isoprene and monoterpenes taken during multiple field campaigns in northern California. The updated canopy model coupled with improved land use and vegetation representation resulted in better agreement between CMAQ isoprene and monoterpene estimates compared with these observations.
\end{abstract}

\section{Introduction}

Volatile organic compounds (VOCs) are known to contribute to ozone $\left(\mathrm{O}_{3}\right)$ and particulate matter less than 2.5 microns in diameter $\left(\mathrm{PM}_{2.5}\right)$ formation in the troposphere. Elevated concentrations of $\mathrm{O}_{3}$ and $\mathrm{PM}_{2.5}$ have known deleterious health effects (Bell et al., 2004; Pope and Dockery, 2006; Pope et al., 2006) and climate implications. Biogenic VOCs (BVOCs) are highly reactive and contribute to local and continental scale $\mathrm{O}_{3}$ and $\mathrm{PM}_{2.5}$ (Carlton et al., 2009; Chameides et al., 1988; Wiedinmyer et al., 2005). Terrestrial biogenic emissions are an important input to photochemical transport models which are used to quantify the air quality benefits and climate impact of emission control plans. Despite the important role of BVOCs in atmospheric chemistry, the spatial representation of vegetation species, their emission factors, and canopy parameterization remain highly uncertain.

Isoprene, a highly reactive $\mathrm{BVOC}$, contributes to $\mathrm{O}_{3}$ (Chameides et al., 1988) and influences secondary organic aerosol (SOA) formation (Carlton et al., 2009). Monoterpenes and sesquiterpenes are BVOCs known to react in the atmosphere to form SOA (Sakulyanontvittaya et al., 2008). The impact of BVOC emissions on these pollutants is significant enough that model simulations have been conducted to explicitly quantify their impact (Fann et al., 2013; Kwok et al., 2013; Lefohn et al., 2014). The Biogenic Emission Inventory System (BEIS) (Pierce and Waldruff, 1991; Schwede et al., 2005) estimates these and other BVOC species and has been used extensively to support scientific (Carlton and Baker, 2011; Fann et al., 2013; Kelly et al., 2014; Simon et al., 2013; Wiedinmyer et al., 2005) and regulatory (US Envi- 
ronmental Protection Agency, 2010, 2011, 2012) model applications.

BVOC emissions are highly variable among different types of vegetation, therefore the representation of vegetative coverage is critically important for accurate spatial distribution of emissions. Northern California has a large gradient in high-isoprene-emitting vegetation extending from the Sacramento valley eastward toward the Sierra Nevada (Dreyfus et al., 2002; Karl et al., 2013; Misztal et al., 2014). Many counties in California have been designated as "nonattainment" areas for both the $8 \mathrm{~h} \mathrm{O}_{3}$ and $\mathrm{PM}_{2.5}$ National Ambient Air Quality Standards (NAAQS). Recent field studies measuring BVOC concentrations in this area provide a unique opportunity to evaluate photochemical-model-estimated BVOC ambient concentrations using an existing (BEIS version 3.14) and updated version of BEIS (version 3.61) and input vegetation data. Ground measurements of BVOC concentrations were made during the Carbonaceous Aerosols and Radiative Effects Study (CARES) campaign in an urban area (Sacramento) and at a site downwind from Sacramento (Cool, CA) that is located near vegetation known for high isoprene emissions (Zaveri et al., 2012). The Biosphere Effects on Aerosols and Photochemistry Experiment (BEARPEX) 2009 campaign provides BVOC measurements at a remote location in the Sierra Nevada foothills to the east of Sacramento and Cool (Beaver et al., 2012), an area of high monoterpene emitting vegetation.

In this paper, BVOC emissions estimated with the existing, version 3.14 (Schwede et al., 2005), and updated version of BEIS, version 3.61, are input to the Community Multiscale Air Quality (CMAQ) photochemical transport model (Hutzell et al., 2012; Byun and Schere, 2006; Foley et al., 2010) and estimated BVOC ambient concentrations are compared to surface observations at these field campaigns in central and northern California. Canopy coverage and vegetation species data have been updated with the United States Forest Service Forest Inventory and Analysis (FIA) version 5.1 database and 2006 United States Geological Survey National Land Cover Database (NLCD) using more spatially explicit techniques for tree species allocation. BEIS 3.61 has been updated with new a canopy model of leaf temperature for emissions' estimation. Canopy leaf temperature estimates are also compared with infrared skin temperature measurements over a grass canopy made at Duke Forest. BVOC estimates from the Model of Emissions of Gases and Aerosols from Nature (MEGAN) (Guenther et al., 2012) are also input to CMAQ and model predictions are compared with field study measurements to provide additional context for BEIS updates.

\section{Methods}

\subsection{Land cover and vegetation speciation}

BEIS 3.14 used the BELD 3 land use data set based on combined US county-level USDA-USFS Forest Inventory and Analysis (FIA) vegetation speciation circa 1992 information with the 1992 USGS land cover information (Kinnee et al., 1997). A new land cover data set (BELD 4) integrating multiple data sources has been generated at $1 \mathrm{~km}$ resolution covering North America. Land use categories are based on the 2001 to 2011 National Land Cover Data set (NLCD), 2002 and 2007 USDA census of agriculture county-level cropping data, and Moderate Resolution Imaging Spectroradiometer (MODIS) satellite products where more detailed data were unavailable.

Fractional tree canopy coverage is based on the $30 \mathrm{~m}$ resolution 2001 NLCD canopy coverage (http://nationalmap. gov/landcover.html; Homer et al., 2004) and land cover is based on $30 \mathrm{~m}$ resolution 2006 NLCD Land Cover data. The 2001 canopy data were used because there was no canopy product developed for the 2006 NLCD. Land cover for areas outside the conterminous United States is based on $500 \mathrm{~m}$ MODIS land cover data for 2006 (https://lpdaac.usgs.gov/dataset_discovery/modis/ modis_products_table/mcd12q1; MCD12Q1) using the International Geosphere Biosphere Programme classification.

Vegetation speciation is based on multiple data sources. Tree species are based on 2002-2013 Forest Inventory and Analysis (FIA) version 5.1 and crop species information is based on 2002 and 2007 USDA census of agriculture data. The FIA includes approximately 250000 representative plots of species fraction data that are within approximately $75 \mathrm{~km}$ of one another in areas identified as forest by the NLCD tree canopy coverage. USDA census of agriculture data is available on a state and county level only and has been used to refine the agricultural classes to the NLCD agricultural land use categories.

FIA version 5.1 location data have been degraded to enhance landowner privacy in accordance with the Food Security Act of 1985 (O'Connell et al., 2012). The provided locations are accurate within approximately $1.6 \mathrm{~km}$ with most plots being within $0.8 \mathrm{~km}$ of the reported coordinates and have accurate state and county identification codes (O'Connell et al., 2012). BELD 3 FIA vegetation specie fractions were aggregated to county level based on national aboveground biomass estimates for deciduous, pine, juniper, fir, and hemlock species. In the BELD 4 data set, FIA plotlevel forest biomass $\left(\mathrm{kg} \mathrm{ha}^{-1}\right)$ and specific leaf area $\left(\mathrm{g} \mathrm{m}^{-2}\right)$ were estimated using the allometric scaling methods of Jenkins et al. (2003) and Chojnacky et al. (2014). Plot-level tree biomass estimates were corrected for sampled bole biomass and scaled to a per-hectare basis following O'Connell et al. (2012). The plot-level total and foliage biomass estimates are then extrapolated to the continental United States by spa- 
tial kriging using the plots' longitude, latitude, and elevation as predictors and weighted by the NLCD canopy fraction. If elevation was not reported at the plot, then elevation was supplied by a digital elevation data from the Weather and Research Forecasting (WRF) model. Kriging to the 4 by $4 \mathrm{~km}$ grid resolution was done in 140 by $140 \mathrm{~km}$ moving windows with a $50 \%$ overlap to address regional differences in spatial gradients. A buffer that extended beyond this window was determined by a semivariogram. Similarly, tree species biomass information was kriged with the additional constraint of the NLCD land use categories (deciduous, evergreen, or mixed forest) applied as weights.

The fractional species composition of the NLCD canopy coverage was then calculated and the FIA 5.1 species were aggregated to the BELD 4 species (Table S1 and Fig. S1 in the Supplement). The NLCD land cover defines trees as greater than $5 \mathrm{~m}$ tall, forest refers to greater than $20 \%$ canopy coverage, with deciduous forests having more than $75 \%$ foliage shed in winter and evergreen forests having more than $75 \%$ of foliage retained in winter (http://www. mrlc.gov/nlcd06_leg.php). These tolerances were used constraining the kriging processes. Total kriged biomass estimates were quantitatively evaluated against the independent estimates of Blackard et al. (2008). Species-specific data in BELD 4 were qualitatively evaluated against the range maps of Critchfield and Little (1966) and Little (1971, 1976). This kriging approach provides an estimate of vegetation speciation for land cover categories where information is not readily available, such as urban, grassland, and shrublands. While this kriging approach may provide better spatial estimates of biomass and vegetation type for most areas of the continental United States, it is possible that small areas with vegetation and biomass dramatically different than the surrounding region (e.g., some urban areas) will likely need further refinement.

\subsection{Biogenic emissions}

MEGAN and BEIS are both used to support regional- to continental-scale $\mathrm{O}_{3}$ and $\mathrm{PM}_{2.5}$ photochemical model applications (Carlton and Baker, 2011). Both modeling systems estimate emissions based on vegetation type, meteorological variables, and canopy characteristics (Carlton and Baker, 2011). MEGAN and BEIS both estimate BVOC emissions following the empirical algorithm initially developed by Guenther et al. (2006). The emission factors between MEGAN and BEIS differ as MEGAN uses emission factors for 16 different global plant functional types (Guenther et al., 2012) while BEIS uses species- or species-group-specific emission factors where available and MODIS plant function types where no species-specific data are available, see Sect. 2.1. The canopy models between BEIS and MEGAN also differ. MEGAN uses a five-layer canopy model where leaf temperature is iteratively solved for each layer by adjusting the MEGAN-modeled latent, sensible heat fluxes, and outgoing long wave radiation to minimize the incoming and outgoing energy balance for the modeled leaf (Eq. 1). BEIS approximates the leaf temperature for sun and shaded layers of the canopy from the surface energy and momentum balance in the meteorological model as detailed in Sect. 2.3. These models have been evaluated against BVOC measurements in the central United States (Carlton and Baker, 2011) and Texas (Warneke et al., 2010) but little evaluation of both models has been done for California. BEIS version 3.14 provides a baseline for comparison of BEIS version 3.61 that includes enhancements described here.

BEIS version 3.61 estimates emissions for 33 volatile organic compounds, carbon monoxide, and nitric oxide. Table 1 shows the complete list of compounds estimated by BEIS with mapping to contemporary gas-phase chemical mechanisms SAPRC07T and CB6. BEIS estimates isoprene, 14 unique monoterpene compounds, and total sesquiterpenes. In addition, emissions are estimated for 16 other volatile organic compounds and an aggregate group of other unspeciated VOC. All biogenic VOC emissions are a function of leaf temperature while only isoprene, methanol, and MBO are a function of both leaf temperature and photosynthetically activated radiation (PAR). All species emissions have small indirect impacts from PAR via the canopy module.

Inputs to BEIS include normalized emissions for each vegetation species, gridded vegetation species, temperature, and PAR. Temperature and PAR can be provided from prognostic meteorological models, such as WRF or other sources, such as satellite products (Pinker and Laszlo, 1992; Pinker et al., 2002) or ambient measurements. The BELD 4 database contains vegetation specie information for 275 different vegetation categories (Table S1). Table 2 shows emission rates for each emitted compound by aggregated vegetation type to illustrate variability in emissions. The variability in BEIS emission rates is greater than MEGAN 2.1 (Guether et al., 2012) due to the more detailed representation of vegetation species. These vegetation types include 20 MODIS and 21 NLCD land cover categories, and 20 different types of both irrigated and non-irrigated crops (40 total). The remaining categories include tree species, much of which are broadleaf (e.g., oak) and needle leaf (e.g., fir) species. A gridded file indicating leaf-on dates based on the 2009 modeled meteorologic bioseasons file, is also provided as input to BEIS. In the future, leaf-out and leaf-fall dates will be matched with LAI data. Plant genus type LAIs for summer and winter are estimated following Kinnee et al. (1997). However, it is unlikely the current simple leaf-on parameterization will impact typical regulatory assessments since elevated $\mathrm{O}_{3}$ and $\mathrm{PM}_{2.5}$ organic carbon events often happen outside the spring and fall seasons.

For various sensitivity studies presented here, BEIS 3.14 is applied with BELD 3 vegetation data, WRF temperature, and both WRF and satellite-derived estimates of PAR. BEIS 3.61 is applied similarly but with BELD 3 and BELD 4 
Table 1. Species emissions estimated by BEIS and mapping to the SAPRC07T and CB6r2 gas-phase chemical mechanism lumped species.

\begin{tabular}{|c|c|c|c|c|}
\hline No. & Emitted specie & $\begin{array}{l}\text { BEIS } \\
\text { Abbreviation }\end{array}$ & SAPRC07 species & CB6r2 species \\
\hline 1 & ethene & ETHE & ETHENE & ETH \\
\hline 2 & ethane & ETHA & ALK1 & ETHA \\
\hline 3 & methanol & METH & MEOH & MEOH \\
\hline 4 & ethanol & ETHO & ALK3 & ETOH \\
\hline 5 & formaldehyde & FORM & $\mathrm{HCHO}$ & FORM \\
\hline 6 & acetaldehyde & ACTAL & $\mathrm{CCHO}$ & ALD2 \\
\hline 7 & formic acid & FORAC & $\mathrm{HCOOH}$ & FACD \\
\hline 8 & acetic acid & ACTAC & $\mathrm{CCOOH}$ & AACD \\
\hline 9 & propene & PROPE & OLE1 & $33.3 \%$ PAR $+66.7 \%$ OLE \\
\hline 10 & hexenol & HEXE & OLE1 & $33.3 \%$ PAR $+66.7 \%$ IOLE \\
\hline 11 & hexenyl acetate & HEXY & OLE1 & $37.5 \% \mathrm{PAR}+50 \% \mathrm{IOLE}+12.5 \% \mathrm{NR}$ \\
\hline 12 & butenone & BUTO & OLE1 & $50 \% \mathrm{PAR}+50 \%$ OLE \\
\hline 13 & 2-methyl-3-buten-2-ol & $\mathrm{MBO}$ & OLE2 & $60 \% \mathrm{PAR}+40 \%$ OLE \\
\hline 14 & butene & BUTE & OLE2 & $50 \% \mathrm{PAR}+50 \%$ OLE \\
\hline 15 & acetone & ACET & ACETONE & ACET \\
\hline 16 & hexanal & HEXA & $\mathrm{RCHO}$ & $66.7 \%$ PAR $+33.3 \%$ ALDX \\
\hline 17 & other reactive VOCs & ORVOC & $10 \%$ OLE $2+85 \%$ ALK $2+5 \%$ NR & $80 \%$ PAR $+20 \%$ OLE \\
\hline 18 & isoprene & ISOP & ISOPRENE & ISOP \\
\hline 19 & $\alpha$-pinene & APIN & TRP1 & TERP \\
\hline 20 & $\beta$-pinene & BPIN & TRP1 & TERP \\
\hline 21 & $\delta$-3-carene & D3CAR & TRP1 & TERP \\
\hline 22 & $\delta$-limonene & DLIM & TRP1 & TERP \\
\hline 23 & camphene & CAMPH & TRP1 & TERP \\
\hline 24 & myrcene & MYRC & TRP1 & TERP \\
\hline 25 & $\alpha$-terpinene & ATERP & TRP1 & TERP \\
\hline 26 & $\beta$-phellandrene & BPHE & TRP1 & TERP \\
\hline 27 & sabinene & SABI & TRP1 & TERP \\
\hline 28 & $\rho$-cymene & PCYM & TRP1 & TERP \\
\hline 29 & ocimene & OCIM & TRP1 & TERP \\
\hline 30 & $\alpha$-thujene & ATHU & TRP1 & TERP \\
\hline 31 & terpinolene & TRPO & TRP1 & TERP \\
\hline 32 & $\gamma$-terpinene & GTERP & TRP1 & TERP \\
\hline 33 & sesquiterpenes & SESQ & SESQ & SESQ \\
\hline 34 & carbon monoxide & $\mathrm{CO}$ & $\mathrm{CO}$ & $\mathrm{CO}$ \\
\hline 35 & nitric oxide & NO & NO & NO \\
\hline
\end{tabular}

vegetation data to isolate the impact of the updates to the canopy model. Note that the BEIS BVOC emission factors were the same in these BEIS 3.14 and 3.61 simulations. A gridded 0.5 by $0.5^{\circ}$ resolution satellite estimate of PAR from 2009 was processed to match the model domain specifications and input to both BEIS and MEGAN. The satellite estimates are based on the GEWEX Continental Scale International Project and GEWEX Americas Prediction Project Surface Radiation Budget (www.atmos.umd. edu/ srb/gcip/gcipsrb.htm) (Pinker et al., 2002). MEGAN version 2.1 (Guenther et al., 2014, 2012) with version 2011 North America Leaf Area Index and Plant Functional Type (Guenther et al., 2014) was applied with WRF-estimated temperature and PAR and also with satellite-derived PAR.

\subsection{Canopy Model - leaf temperature update}

BEIS 3.61 includes a two-layer canopy model. Layer structure varies with light intensity and solar zenith angle. Both layers of the canopy model include estimates of sunlit and shaded leaf area based on solar zenith angle and light intensity, direct and diffuse solar radiation, and leaf temperature. BEIS 3.14 previously used $2 \mathrm{~m}$ temperature to represent canopy temperature for emissions' estimation even though BVOC emission factors are typically based on leaf temperature (Niinemets et al., 2010). The canopy model has been updated to use land surface physics from the WRF model and air-surface exchange algorithms from the CMAQ model to approximate leaf temperature using an energy balance for the sunlit and shaded portion of each canopy layer. Emissions 


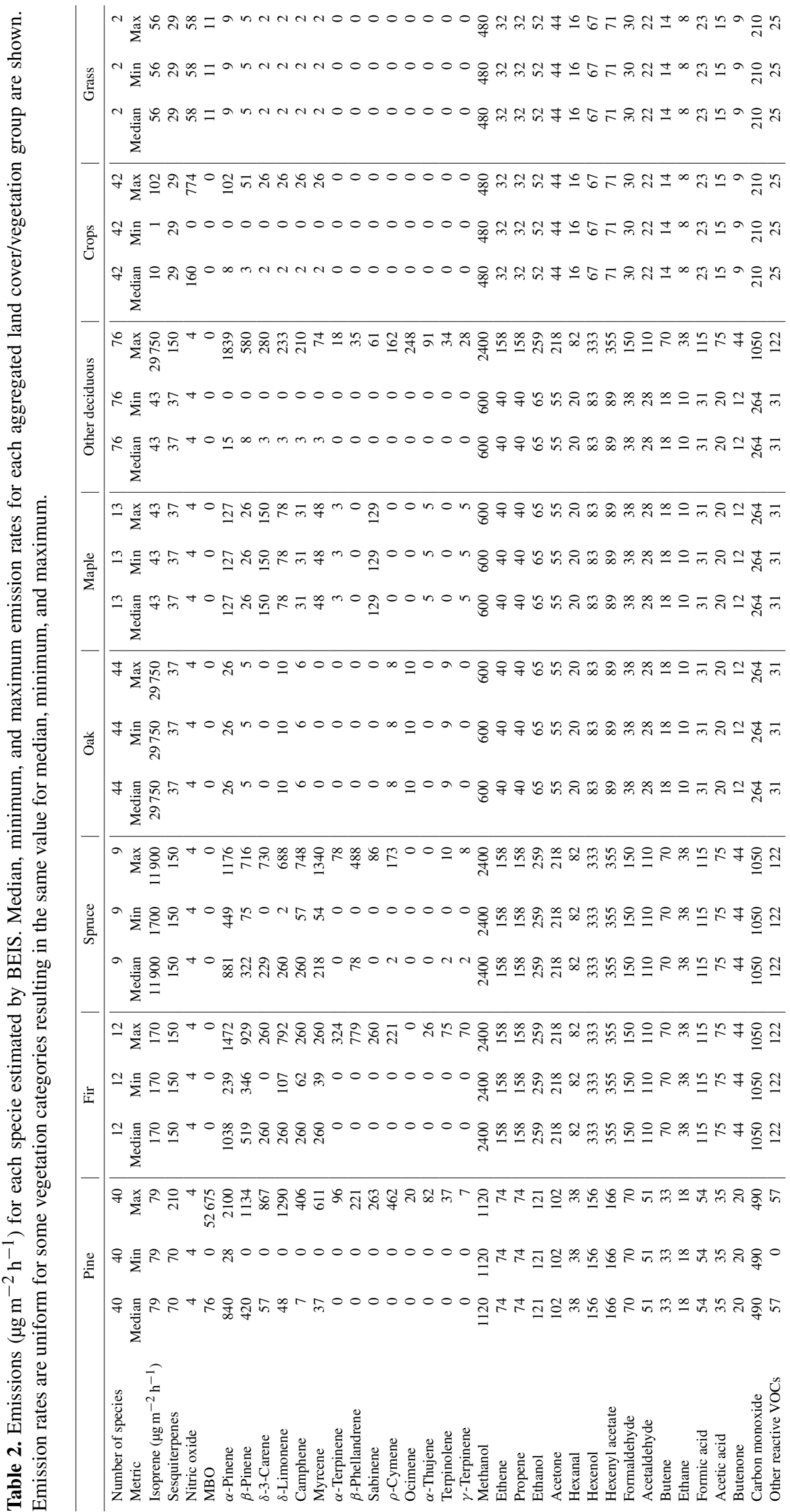


are estimated for sunlit and shaded fractions of the canopy and summed over the two layers for total canopy emissions.

A simple two-big-leaf (sun and shade) temperature model was developed based on a radiation balance. The leaf radiation balance is solved for both the sun (Eq. 1) and shaded (Eq. 2) leaf sides in each layer.

Sun leaf

$R_{\text {sun }}+\mathrm{IR}_{\text {in }}-\mathrm{IR}_{\text {out }}-H-\lambda E_{\text {sun }}+G=0$

shade leaf

$R_{\text {shade }}+\mathrm{IR}_{\text {in }}-\mathrm{IR}_{\text {out }}-H-\lambda E_{\text {shade }}+G=0$,

where $I R_{i n}$ is the incoming infrared radiation, $I R_{\text {out }}$ is the outgoing infrared radiation, $\lambda$ is the latent heat of evaporation, $E_{\text {sun }}$ and $E_{\text {shade }}$ are the latent heat flux from sun and shade leaves, respectively, $H$ is the sensible heat flux, and $G$ is the soil heat flux. To maintain the same energy balance as WRF, it was assumed that $E$ scales linearly with sunlit and shaded fractions of the canopy. Note that conventionally $G$ is positive when the soil is being heated and negative when the soil is cooling while the sign convention of the other variables is relevant to heating and cooling of the atmosphere. $R_{\text {sun }}$ is the total incoming solar radiation from the meteorological model and $R_{\text {shade }}$ is modeled using the attenuation, scattering, and diffuse radiation from Weiss and Norman (1985).

The infrared budget is parameterized as

$$
\begin{aligned}
& \mathrm{IR}_{\text {in }}=\varepsilon_{\mathrm{atm}} \sigma T_{\mathrm{atm}}^{4} \\
& \mathrm{IR}_{\text {out }}=\varepsilon_{\text {leaf }} \sigma T_{\text {leaf }}^{4},
\end{aligned}
$$

where $\varepsilon_{\text {atm }}$ and $\varepsilon_{\text {leaf }}$ are the emissivities of the atmosphere and leaf, respectively, $\sigma$ is the Boltzmann constant, and $T_{\text {atm }}$ and $T_{\text {leaf }}$ are the atmospheric and leaf temperatures, respectively.

$E$ is parameterized as

$$
E=\rho_{\text {atm }} \frac{e_{\mathrm{s}}\left(T_{\text {leaf }}\right)-e_{\mathrm{a}}}{R_{\mathrm{w}, \text { leaf }} P_{\mathrm{atm}}},
$$

where $\rho_{\text {atm }}$ is the atmospheric density, $e_{\mathrm{S}}\left(T_{\text {leaf }}\right)$ is the saturation vapor pressure at the leaf, $e_{\mathrm{a}}$ is the atmospheric vapor pressure, $R_{\mathrm{w}, \text { leaf }}$ is the resistance to water vapor transport from the leaf to atmosphere, and $P_{\text {atm }}$ is the atmospheric pressure at the surface.

The saturation vapor pressure of the leaf is defined as

$e_{\mathrm{S}}\left(T_{\text {leaf }}\right)=a e^{\frac{b\left(T_{\text {leaf }}-273.15\right)}{T_{\text {leaf }}-c}}$,

where the empirical coefficients are $a=611.0 \mathrm{~Pa}, b=17.67$, and $c=29.65^{\circ} \mathrm{C}$.

$H$ is parameterized following the WRF Pleim-Xiu (PX) land surface model (Skamarock et al., 2008) as

$H=\frac{\rho_{\mathrm{atm}} C_{p}\left(\frac{P_{0}}{P_{\mathrm{atm}}}\right)^{R_{\mathrm{atm}} / C_{p}}\left(T_{\text {leaf }}-T_{\mathrm{air}}\right)}{R_{\mathrm{h}, \text { leaf }}}$, where $C_{p}$ is the specific heat of air, $P_{0}$ is the STP pressure, $R_{\mathrm{atm}}$ is the gas constant for dry air, and $R_{\mathrm{h} \text {,leaf }}$ is the resistance to heat advection between the atmosphere and leaf. Note that $R_{\mathrm{h}, \text { leaf }}$ must consider advection from both the upper (adaxial) and lower (abaxial) surfaces of the leaf.

The $T_{\text {leaf }}^{4}$ variable and Eq. (6) prevents an analytical solution. Thus the approximation from Campbell and Norman (1998) is used.

The $T_{\text {leaf }}^{4}$ term is simplified as follows:

$$
\begin{aligned}
\varepsilon_{\text {leaf }} \sigma T_{\text {leaf }}^{4} \approx & \varepsilon \sigma T_{\text {atm }}^{4} \\
& +\frac{\rho_{\text {atm }} C_{p}\left(\frac{P_{0}}{P_{\text {atm }}}\right)^{R_{\text {atm }} / C_{p}}\left(T_{\text {leaf }}-T_{\text {air }}\right)}{R_{\mathrm{r}, \text { leaf }}},
\end{aligned}
$$

where $R_{\mathrm{r} \text {, leaf }}$ is the atmospheric radiative resistance $\sim 230 \mathrm{~s} \mathrm{~m}^{-1}$ (Monteith and Unsworth, 2013).

Equation (5) is then further simplified:

$$
\begin{aligned}
\lambda \rho_{\mathrm{atm}} \frac{e_{\mathrm{s}}\left(T_{\text {leaf }}\right)-e_{\mathrm{a}}}{R_{\mathrm{w}, \text { leaf }} P_{\mathrm{atm}}} \approx & \lambda S\left(T_{\mathrm{atm}}\right) \frac{\left[T_{\text {leaf }}-T_{\mathrm{atm}}\right]}{R_{\mathrm{w}, \text { leaf }}} \\
& +\lambda \rho_{\mathrm{atm}} \frac{e_{\mathrm{s}}\left(T_{\mathrm{atm}}\right)-e_{\mathrm{a}}}{P_{\mathrm{atm}} R_{\mathrm{w}, \text { leaf }}},
\end{aligned}
$$

where

$S=\frac{\mathrm{d} e_{\mathrm{S}}(T)}{\mathrm{d} T}$.

Equations (1), (3), (5), (7), (8), and (9) are algebraically combined to estimate the sunlit leaf temperature assuming that $\varepsilon_{\text {atm }}=\varepsilon_{\text {leaf }}$.

$$
\begin{aligned}
& T_{\text {sun,leaf }} \approx T_{\text {atm }} \\
& +\frac{R_{\text {sun }}+G-\lambda \rho_{\text {atm }} \frac{e_{\mathrm{s}}\left(T_{\text {atm }}\right)-e_{\mathrm{a}}}{P_{\text {atm }} R_{\mathrm{w}, \text { leaf }}}}{\rho_{\mathrm{atm}}\left[\left(\frac{P_{0}}{P_{\mathrm{atm}}}\right)^{R_{\mathrm{atm}} / C_{p}} C_{p}\left(\frac{1}{R_{\mathrm{h}, \text { leaf }}}+\frac{1}{R_{\mathrm{r}, \text { leaf }}}\right)+\lambda S\left(\frac{1}{R_{\mathrm{w}, \text { leaf }}}\right)\right]} .
\end{aligned}
$$

Equations (2), (3), (5), (7), (8), and (9) are combined to estimate the shaded leaf temperature:

$$
\begin{aligned}
& T_{\text {shade,leaf }} \approx T_{\text {atm }} \\
& +\frac{R_{\text {shade }}+G-\lambda \rho_{\text {atm }} \frac{e_{\mathrm{s}}\left(T_{\text {atm }}\right)-e_{\mathrm{a}}}{P_{\mathrm{atm}} R_{\mathrm{w}, \text { leaf }}}}{\rho_{\mathrm{atm}}\left[\left(\frac{P_{0}}{P_{\mathrm{atm}}}\right)^{R_{\text {atm }} / C_{p}} C_{p}\left(\frac{1}{R_{\mathrm{h}, \text { leaf }}}+\frac{1}{R_{\mathrm{r}, \text { leaf }}}\right)+\lambda S\left(\frac{1}{R_{\mathrm{w}, \text { leaf }}}\right)\right]} .
\end{aligned}
$$

The sunlit leaf area index, $\mathrm{LAI}_{\text {Sun }}$, is estimated following (Campbell and Norman, 1998):

$\mathrm{LAI}_{\text {Sun }}=\int_{0}^{\mathrm{LAI}} e^{-k_{\mathrm{be}}(\Psi) L} \mathrm{~d} L$,

where LAI is the total canopy leaf area index, $k_{\mathrm{be}}$ is the extinction coefficient for direct beam incoming solar radiation as a function of the solar zenith angle, and $\Psi$ follows Campbell and Norman (1998). The shaded leaf area index, LAI ${ }_{\text {Shade }}$, is then estimated as follows:

$\mathrm{LAI}_{\text {Shade }}=\mathrm{LAI}-\mathrm{LAI}_{\text {Sun }}$. 
BVOC emission fluxes, $F_{i}$, are estimated similar to MEGAN (Guenther et al., 2006) for sunlit and shaded fractions of the canopy

$$
F_{i, j}=E_{i} \gamma_{\mathrm{PAR}, i, j} \gamma_{T, i, j} \mathrm{LAI}_{j},
$$

where $E_{i}$ is the emission factor or BVOC species $i, \gamma_{\mathrm{PAR}}$ is the emission activity factor for PAR (currently only applied to isoprene, methanol, and MBO), $\gamma_{T}$ is the emission activity factor for leaf temperature following Guenther et al. (1993), and $j$ is the index for sunlit or shaded leaves. $\gamma_{\mathrm{PAR}}$ integrates the PAR emissions activity factor of Guenther et al. (1993) for sunlit and shaded layers following Niinemets et al. (2010):

$\gamma_{\mathrm{PAR}, i, \text { Sunlit }}=\operatorname{PAR} C_{L} \int_{0}^{\text {LAISun }} \frac{e^{-2 k_{\mathrm{dd}} L}}{\sqrt{1+\alpha^{2} \mathrm{PAR}^{2} e^{-2 k_{\mathrm{dd}} L}}} \mathrm{~d} L$

$\gamma_{\mathrm{PAR}, i, \text { Shaded }}=\operatorname{PAR} C_{L} \int_{\mathrm{LAI}_{\text {Sun }}}^{\mathrm{LAI}} \frac{e^{-2 k_{\mathrm{dd}} L}}{\sqrt{1+\alpha^{2} \mathrm{PAR}^{2} e^{-2 k_{\mathrm{dd}}}}} \mathrm{d} L$,

where $k_{\mathrm{dd}}$ is the net attenuation coefficient for direct and diffuse PAR, and $\alpha$ and $C_{L}$ are empirical coefficients, 0.0027 and 1.066, respectively, defined in Guenther et al. (1993).

\subsection{Photochemical model background, inputs, and application}

Chemical species are estimated using the Community Multiscale Air Quality Model (CMAQ) version 5.0.2 (www. cmaq-model.org) photochemical grid model. CMAQ was applied with SAPRC07TB gas-phase chemistry (Hutzell et al., 2012), ISORROPIA II inorganic chemistry (Fountoukis and Nenes, 2007), secondary organic aerosol treatment (Carlton et al., 2010), and aqueous-phase chemistry that oxidizes sulfur, glyoxal, and methylglyoxal (Carlton et al., 2008; Sarwar et al., 2013). The Weather Research and Forecasting (WRF) Advanced Research WRF core (ARW) version 3.3 (Skamarock et al., 2008) was used to generate gridded meteorological inputs for CMAQ and emissions models. While not coincident with this study, this WRF configuration compared well with mixing layer height and surface measurements of temperature and winds in central California during the summer of 2010 (Baker et al., 2013). For model performance evaluation presented here, model estimates are paired with measurements using the grid cell where the measurement was located. Measurements are paired in time with hourly model estimates with the closest model hour (Simon et al., 2012).

The model domain covers central and northern California with $4 \mathrm{~km}^{2}$ grid cells. The vertical layers are terrainfollowing hydrostatic pressure coordinates ranging from the surface to $50 \mathrm{mb}$ is resolved with 34 layers. Layers nearest the surface are most finely resolved with an approximate height of $38 \mathrm{~m}$ for layer 1 . The modeling period extends from 3 June through 31 July 2009 to be coincident with the BEARPEX field campaign and minimize the influence of initial conditions on model estimates. Initial conditions and boundary inflow are from a coarser CMAQ simulation covering the continental United States. Inflow to the coarser simulation is from a global 2009 application of the GEOS-CHEM (v8-03-02) model (http://acmg.seas.harvard. edu/geos/) (Henderson et al., 2014).

Stationary point sources are based on 2009 specific emissions where available and the 2008 National Emission Inventory (NEI) version 2 otherwise. Mobile emissions are interpolated between 2007 and 2011 estimates provided by the California Air Resources Board (CARB) and allocated spatially and temporally using the Spare Matrix Operator Kernel Emissions (SMOKE) model (http://www.cmascenter.org/ smoke). Other non-point and commercial marine emissions are based on the 2008 NEI version 2 (http://www.epa.gov/ $\mathrm{ttn} /$ chief/net/2008inventory.html).

\subsection{Field study measurements}

Between 15 June and 31 July 2009, the BEARPEX study was conducted to study photochemical reactions and products in areas downwind of urban areas with large biogenic influences. The study was located at a managed ponderosa pine plantation in the foothills of the Sierra Nevada $\left(38.90^{\circ} \mathrm{N}\right.$, $120.63^{\circ} \mathrm{W}$ ), located near the University of California's Blodgett Forest Research Station. The measurement site was near Georgetown, CA, approximately $75 \mathrm{~km}$ from Sacramento, CA. Two research towers housed meteorology and atmospheric composition measurements and inlets during BEARPEX 2009. Meteorological measurements were made on the south $12.5 \mathrm{~m}$ tower, including photosynthetically active radiation (PAR) measured by a LI-COR LI190. The second tower $(17.8 \mathrm{~m})$ was located approximately $10 \mathrm{~m}$ north of the meteorological tower and housed most of the atmospheric composition measurements. The inlet used to sample BVOCs was located at the top of the north tower, approximately $9 \mathrm{~m}$ above the ponderosa pine canopy level. BVOCs including isoprene, monoterpenes, methyl vinyl ketone, and methacrolein were quantified using an online gas chromatograph with a flame ionization detector (GC-FID) (Park et al., 2010, 2011). BVOC samples were collected during the first 30 min of every hour, then subsequently analyzed with the GC-FID.

During June 2010, the CARES study was conducted to study the formation of organic aerosols and the subsequent impacts on climate. The study was composed of two surface monitoring sites: T0 and T1. The T0 was located in Sacramento, CA at the American River College campus $\left(38.65^{\circ} \mathrm{N}\right.$, $121.35^{\circ} \mathrm{W}$ ), and the $\mathrm{T} 1$ site was in Cool, $\mathrm{CA}$ on the campus of Northside School $\left(38.87^{\circ} \mathrm{N}, 121.02^{\circ} \mathrm{W}\right)$. The T0 site was 

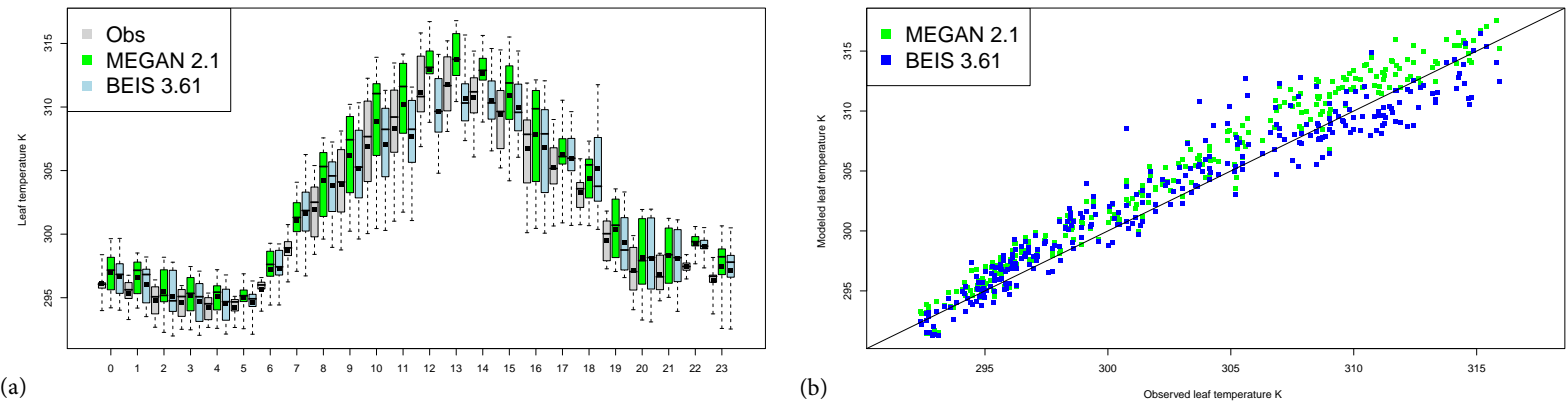

(a)

(b)

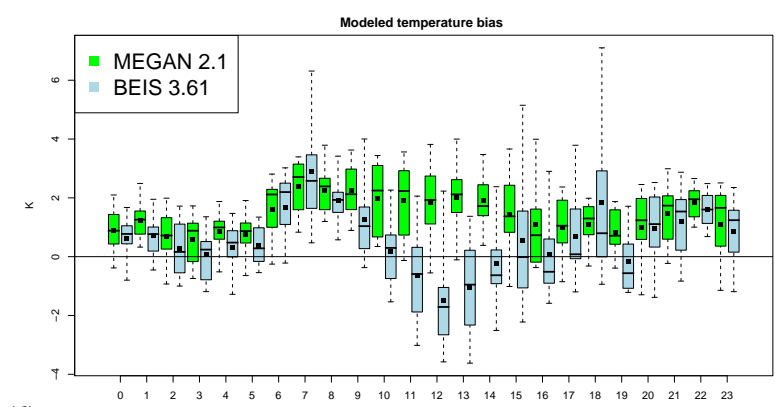

(c)

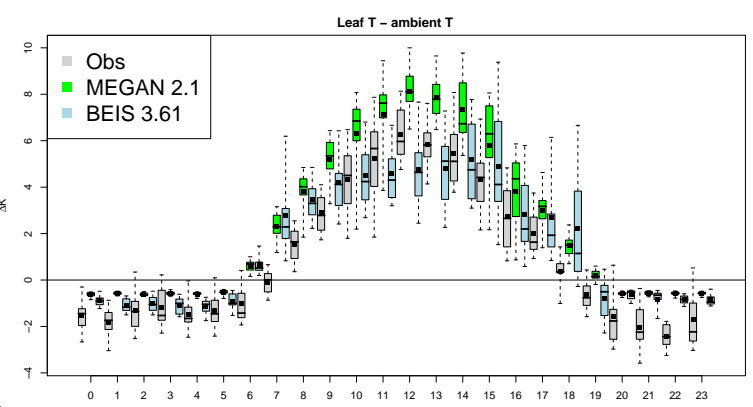

(d)

Figure 1. Diurnal observed, and MEGAN 2.1 and BEIS 3.61 estimated leaf temperatures (a); MEGAN 2.1 and BEIS 3.61 leaf temperature estimates plotted against skin temperature observations (b); observed, MEGAN 2.1, and BEIS 3.61 estimated gradient between leaf and ambient temperatures (c); MEGAN 2.1 and BEIS 3.61 estimated leaf temperature biases (model-observed) (d).

approximately $14 \mathrm{~km}$ northeast of downtown Sacramento, and the T1 site was surrounded by the forested foothills of the Sierra Nevada. Isoprene and monoterpene measurements at the Sacramento (T0) and Cool (T1) CARES ground sites were made with GC-MS and PTRMS, respectively (Zaveri et al., 2012), and sampled via inlets at approximately $10 \mathrm{~m}$ above the surface. PTRMS data were reported as $1 \mathrm{~s}$ measurements approximately every $30 \mathrm{~s}$. GC-MS data were $10 \mathrm{~min}$ collections every $30 \mathrm{~min}$. All observation data were averaged to hourly concentrations before comparison with model estimates.

The sunlight leaf temperature in MEGAN 2.1 and the revised canopy model in BEIS 3.61 were evaluated against observations taken in 2008 at the Blackwood Division of the Duke Forest in Orange County, North Carolina, USA $\left(35.97^{\circ} \mathrm{N}, 79.09^{\circ} \mathrm{W}\right)$. Details regarding the site (FLUXNET, 2014), measurements, and species composition are available elsewhere (Almand-Hunter et al., 2015). Leaf temperature measurements were taken using an infrared temperature sensor (IRTS-P, Apogee Instruments Inc, Logan, UT) mounted on the grassland tower.

\section{Results}

\subsection{Leaf temperature algorithms compared to observations}

The canopy model updates for leaf temperature estimation are evaluated by comparing canopy model output with infrared skin temperature measurements of a grass canopy at the Duke Forest field site in central North Carolina (Fig. 1). BEIS 3.61 canopy model inputs are based on field measurements taken at this location coincident with the skin temperature data collection. The infrared skin temperature measurements do not represent a mean canopy leaf temperature but rather the temperature of the portion of the canopy exposed to the atmosphere. The infrared skin temperature measurement should be warmer than the mean leaf temperature during periods of solar irradiation and cooler during periods of radiative cooling due to the insulating effect of the unexposed portion of the canopy. Only the estimated exposed leaf temperature (Eq. 12) was used in the evaluation to account for this discrepancy between measurements and canopy model output. Figure 1 shows observed and predicted estimates of leaf temperature and difference between leaf and ambient temperature. The average temperature estimated by the BEIS 3.61 canopy model for the top of the canopy compares well with observations (mean bias of $0.3 \mathrm{~K}$ and mean error $1.2 \mathrm{~K}$ ). Top of the canopy leaf temperature estimated by MEGAN 2.1 are 


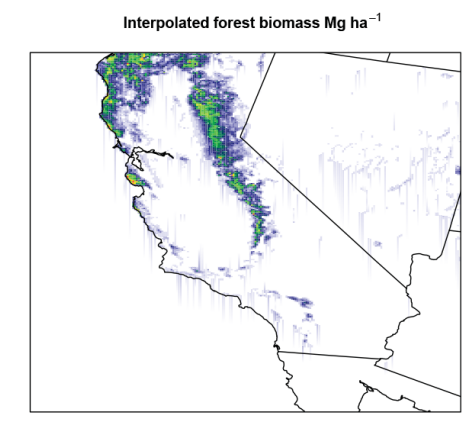

(a)

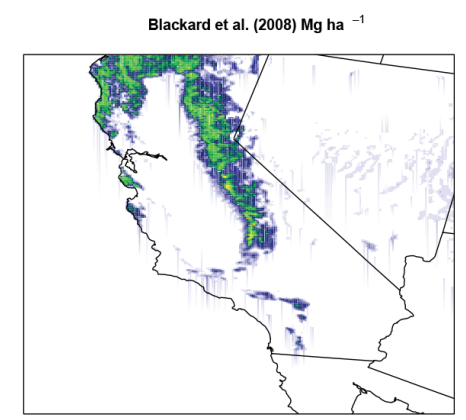

(b)

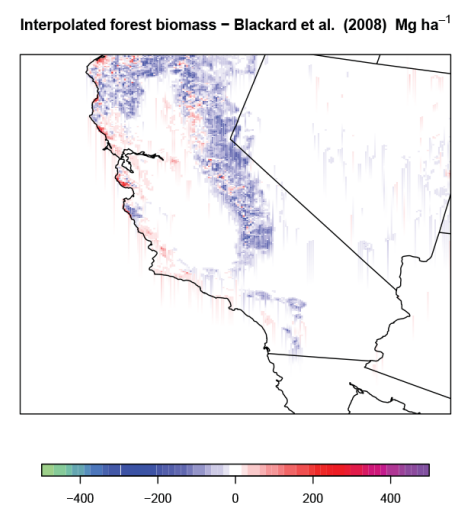

Figure 2. Total aboveground forest biomass $\left(\mathrm{Mg} \mathrm{ha}^{-1}\right.$ ) estimates for BELD 4 (a), Blackard et al. (2008) (b) projected onto the $4 \mathrm{~km} \mathrm{California}$ model domain, and BELD 4 - the $4 \mathrm{~km}$ projected Blackard et al. (2008) (c).

comparable to BEIS 3.61 and the observations at the Duke Forest site.

\subsection{Evaluation of the BELD 4 land use data}

BELD 4 total forest biomass estimates were evaluated against the independent estimates of Blackard et al. (2008). Blackard et al. (2008) created a spatially explicit live forest biomass data set for the United States based on FIA observations mapped to MODIS, $250 \mathrm{~m}$ aggregated NLCD, topographic, and climatic data. Figure 2 shows the BELD 4 and Blackard et al. (2008) estimates of forest biomass for this model domain at $4 \mathrm{~km}$ resolution. The Blackard et al. (2008) $250 \mathrm{~m}$ grid resolution data set was projected and aggregated to the CMAQ $4 \mathrm{~km}$ grid resolution projection using rgdal and raster libraries in R (Bivand et al., 2014). The BELD 4 estimates evaluated well against those of Blackard et al. (2008) with a Pearson's correlation coefficient of $0.872(p<0.001)$ and a mean and median difference in tree biomass in areas where the NLCD data indicated canopy coverage was $-13 \mathrm{~kg} \mathrm{ha}^{-1}(-32 \%)$ and $-0.004 \mathrm{~kg} \mathrm{ha}^{-1}(0 \%)$, respectively. BELD 4 estimates of forest biomass were greater than those of Blackard et al. (2008) in the densely forested areas in the high Sierras and lower in the lower-elevation areas of the domain, primarily in the basin and range areas in the Sacramento valley. The prevalence of the lower-elevation areas with lower biomass estimates drives the difference between the forest biomass estimates. The biomass estimates of Blackard et al. (2008) underpredicted the full range of the biomass variability with overpredictions in areas with low biomass and underpredictions in areas of high biomass compared to the FIA tree survey biomass observations. The total biomass estimates presented here have a larger range, 0 661 vs. $0-499 \mathrm{~kg} \mathrm{ha}^{-1}$ with a median absolute deviation of 2.9 vs. $2.5 \mathrm{~kg} \mathrm{ha}^{-1}$ for areas with NLCD canopy coverage. The lower biomass estimates here and compared to those estimated by Blackard et al. (2008) may be due to our use of $30 \mathrm{~m}$ grid NLCD canopy data rather than their use of $250 \mathrm{~m}$ grid MODIS canopy data or due to the general underestimation of 2001 NLCD canopy fraction product (Nowak and Greenfield, 2012).

There are currently no continental US or global databases to quantitatively evaluate the fractional tree species data coverage developed here. However, the species range maps of Critchfield and Little (1966) and Little $(1971,1976)$ can be used for a qualitative evaluation. The tree species that constituted the largest fraction of biomass observations in the FIA database generally fell within the tree species range maps (Fig. 3). Note that the maps represent a binary distribution of the tree species natural range and the BELD 4 estimates represent a gradient of species density. Species that did not constitute a large fraction in FIA observations typically had a much smaller estimated spatial range than indicated by the range maps. This could partially be due to the criteria, e.g., tree height greater than $5 \mathrm{~m}$, etc., for trees carried over from the NLCD classification scheme or due to sparse sampling of these tree species in the FIA database due to the species scarcity. However, these species likely represent a small fraction of the forest coverage in the domain and a small fraction of the domain-wide BVOC emissions. Also, it is possible that tree coverage has changed in California since the 1970s when the trees were surveyed due to urban planning, plantations, fire, forest growth, and climate change. Future iterations of the BELD data set and the evaluation of the BELD data set can likely be improved by incorporating land cover data with more plant-species-specific information, such as the California Gap Analysis Project (Davis et al., 1998).

\subsection{Describing changes in modeled BVOC estimates in northern California}

Biogenic VOC emissions estimated with BEIS using the new canopy model (BEIS 3.61) and updated vegetation data (BELD 4) are shown for the northern California region in Fig. 4. A similar figure of spatial biogenic emissions estimated with BEIS 3.14 and BELD 3 are shown in Fig. 5. 

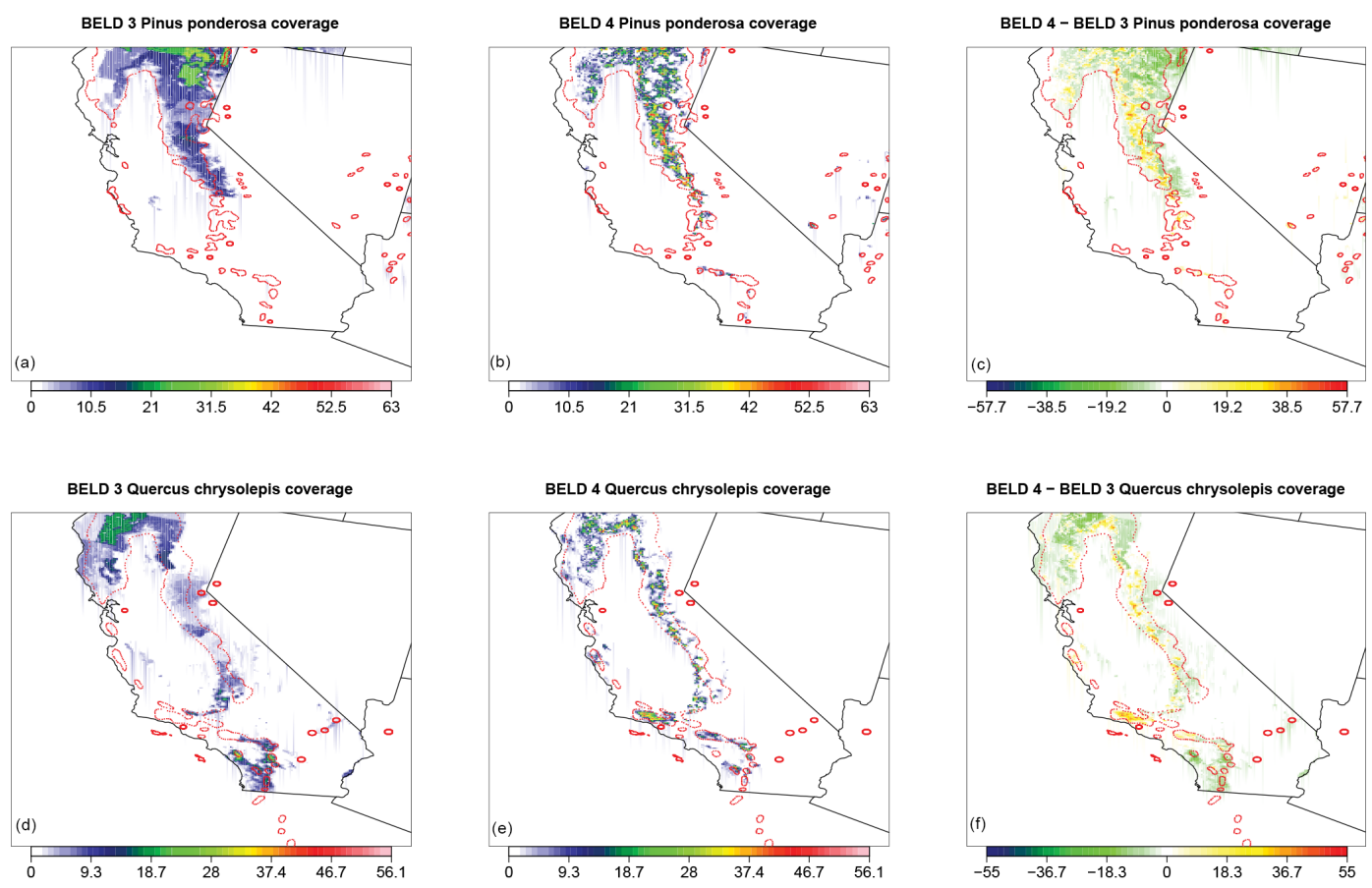

Figure 3. BELD 3 spatial allocation of ponderosa pine (Pinus ponderosa) (a), BELD 4 spatial allocation (b), and the absolute difference between the BELD 4 and BELD 3 spatial allocation (c). BELD 3 spatial allocation of canyon live oaks (Quercus chrysolepis) (d), BELD 4 spatial allocation (e), and the absolute difference between the BELD 4 and BELD 3 spatial allocation (f). The natural range maps of Critchfield and Little (1966) and Little $(1971,1976)$ are represented by the dashed red lines.

In this model domain, isoprene emissions are highest in the foothills of the Sierra Nevada where high-isoprene-emitting vegetation (e.g., oak trees) are located. Monoterpene emissions are highest in the Sierra Nevada Mountains where highemitting needleleaf trees are located. Sesquiterpene emissions are highest in the Sacramento and San Joaquin valleys where grasses are common. Most other biogenic VOC emissions show similar spatial patterns as isoprene or monoterpenes (Fig. 4).

The fractional coverage of oak (high-isoprene-emitting species) and needle leaf trees (high monoterpene emitting species) are shown using BELD 3 and BELD 4 in Fig. S2. The BELD 4 representation shows a higher intensity of fractional coverage in much of the Sierra Nevada as countylevel information is allocated more spatially explicitly than in BELD 3. Smearing out vegetation coverage, as in BELD 3, will lead to lower emission estimates where narrow features, such as the band of oak trees in the western Sierra Nevada foothills, exist and overpredictions in areas that get allocated vegetation that does not exist in that area. Changes in oak and needle leaf fractional coverage between BELD 3 and BELD 4 are notable for both the Cool and Blodgett Forest sites meaning the observation data available at these locations are useful for evaluating the methodology used to generate BELD 4 (Fig. S2).
The updated leaf canopy module increases biogenic VOC emissions throughout California (Fig. 5). The changes to the vegetation input data show increases and decreases in isoprene and monoterpene emissions related to changing spatial allocation of high emitting vegetation species and changes to leaf area estimates. Sesquiterpene emissions generally decrease due to the changes in land use and vegetation for this region (Fig. 5). The new vegetation allocation approach employed here for BELD 4 provides more detailed sub-countylevel representation of emitting species compared to BELD 3 and those changes are reflected in biogenic VOC emission differences.

\subsection{CMAQ estimates compared with CARES and BEARPEX measurements}

The most recent publicly available version of BEIS (version 3.14) and BELD 3 vegetation input were used to provide biogenic emissions for a $4 \mathrm{~km}$ CMAQ simulation covering northern and central California for the period of time coincident with the 2009 BEARPEX field study. Additional simulations were done to illustrate the impact of updating the leaf canopy module in BEIS 3.61 and also how updating vegetation input data has an effect on biogenic VOC model performance. Model runs were also done using satellite-derived PAR as input to BEIS in addition to WRF-estimated solar ra- 

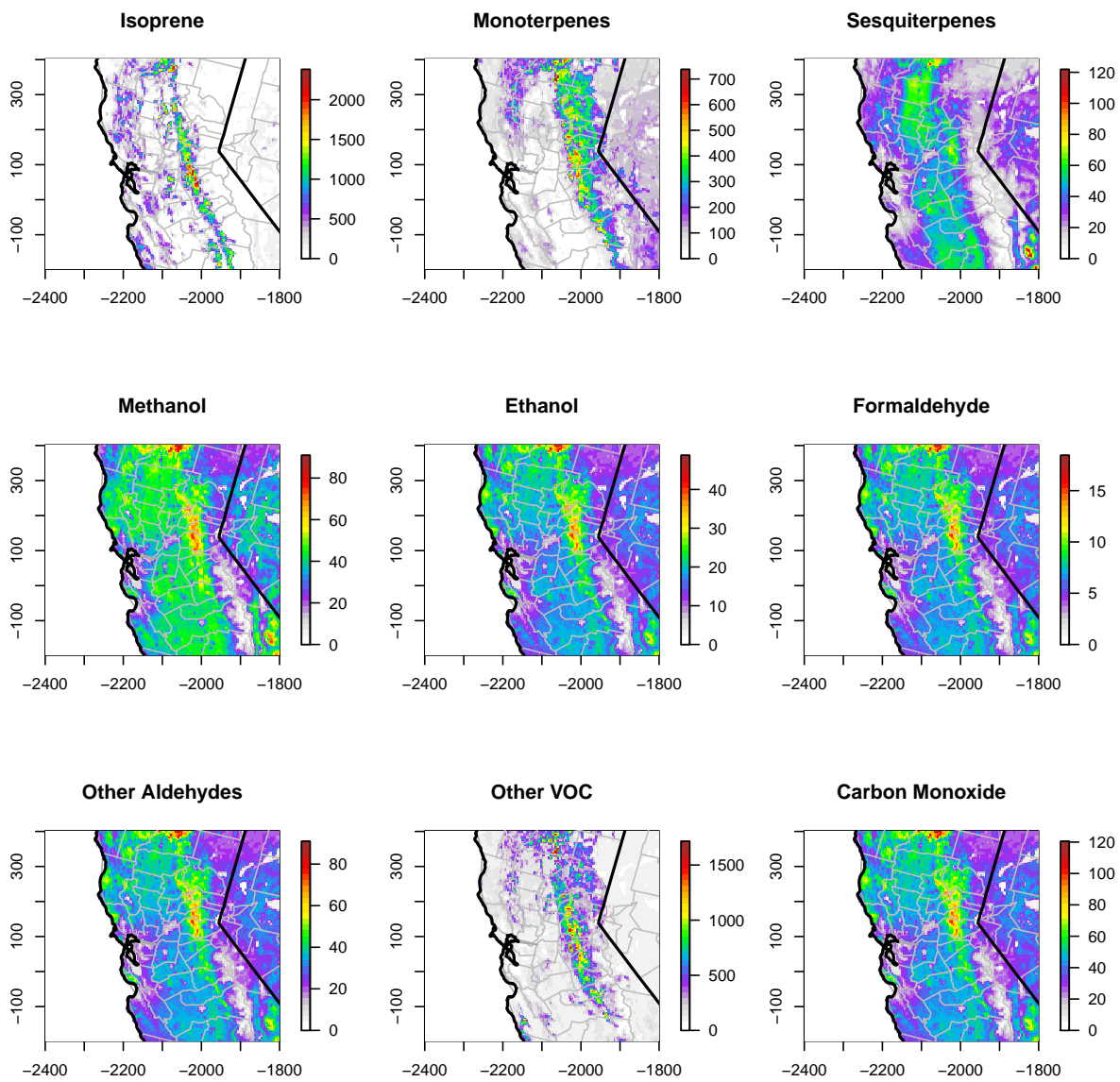

Figure 4. BEIS 3.61/BELD 4 estimated total emissions (tons) for the modeling period.

diation. The MEGAN 2.1 model was also run using WRF and satellite estimates of PAR for the same domain and period.

Temperature and solar radiation used for the biogenic emissions models were compared to measurements at these field sites (Sacramento, Cool, and Blodgett Forest) to determine how meteorological inputs may bias model-estimated BVOC. WRF model evaluation against meteorological variables is summarized in Table 3. The WRF model does well at capturing daytime high temperatures at Blodgett Forest and slightly overestimates daily peak PAR. Daytime minimum temperatures at Blodgett Forest are largely overestimated by WRF (Fig. S3). Temperature maximums and minimums are well characterized at Sacramento and Cool (Figs. S4 and S5) and are similar at these sites during the 2009 and 2010 field study periods (Fig. S3). The satellite-estimated PAR underestimates the ground measurements at Blodgett Forest on certain days but does better at capturing daytime peaks than WRF. In general, meteorological model performance at Blodgett Forest and nearby areas in northern California (Fig. S6) should result in overestimated emissions of isoprene and monoterpenes due to model overestimates in PAR and nighttime ambient temperature. While mixing layer depth has been shown to be well represented by WRF for
California using the configuration used here (Baker et al., 2013), mixing layer depth was not continuously measured at these field sites so it could not be directly evaluated, meaning that differences between modeled and actual surface layer mixing depth and also differences in local- to regional-scale transport could impact CMAQ estimates of biogenic VOC.

Field study measurements of isoprene and monoterpenes taken in 2010 at Sacramento and Cool, and 2009 at Blodgett Forest provide an opportunity to better understand if the changes to BEIS and BELD better reflect the biogenic VOC gradient seen over these sites. Figure 6 shows the observed distribution of isoprene concentrations at Sacramento and Cool from 2010, Blodgett Forest in 2009, and model estimates from 2009 for the baseline CMAQ/BEIS simulation (BEIS 3.14 and BELD 3), canopy model updates (BEIS 3.61), vegetation data updates (BELD 4), and using satellite PAR with all formulation and other input data updates. Measured isoprene concentrations are lowest in Sacramento and highest at Cool where a high density of oak trees exist. The baseline simulation predicts the highest isoprene at Blodgett Forest rather than Cool, but when canopy parameterization updates and vegetation data inputs are used the modeling system captures the gradient in concentration well 

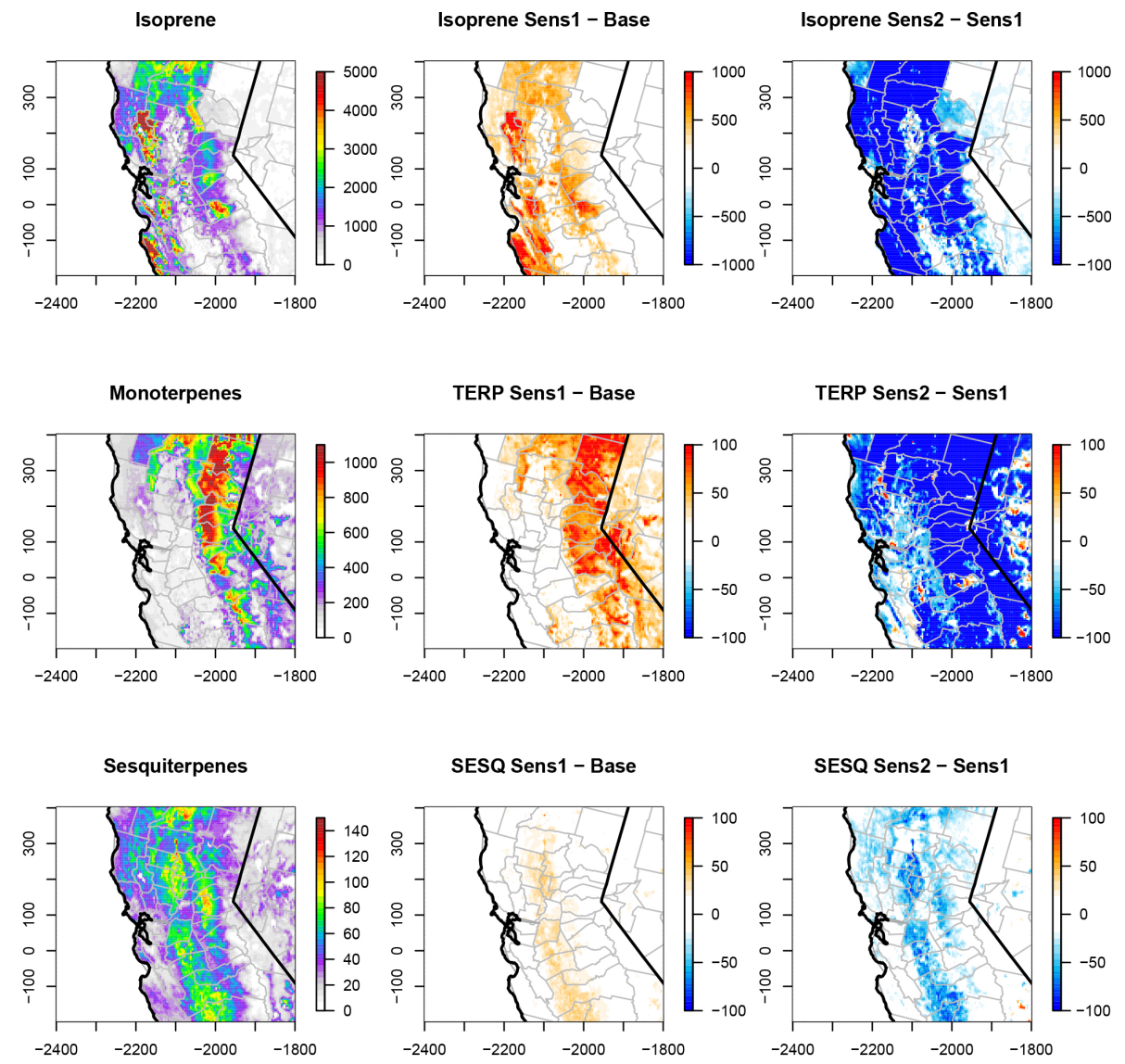

Figure 5. Baseline BEIS 3.14/BELD 3 emissions (tons; left column) and difference between canopy update and baseline BEIS 3.61/BELD 3 (center column) and between the canopy update and land use/vegetation species updates BEIS 3.61/BELD 4 (right column).

across these three sites and also the distribution in observations at each site (Fig. 6).

Measured monoterpenes are highest at Blodgett Forest and lowest at Sacramento (Fig. 7). The baseline model captured this gradient but notably overestimated monoterpenes at Cool. When BELD 4 is used as input, the modeling system compares much closer to observations at Cool and begins to slightly underestimate at Blodgett Forest. The use of satellite PAR rather than solar radiation estimated by WRF does little to change model performance of isoprene. Monoterpenes are not directly sensitive to PAR input and change little due to indirect use of PAR in the canopy model.

The MEGAN 2.1 model generally captures the gradient in observations between sites for isoprene and monoterpenes, but predicts much higher isoprene concentrations at each site compared to observations (see Fig. 6). This is consistent with other studies comparing MEGAN 2.1 isoprene flux with measurements in the Sierra Nevada of northern California (Misztal et al., 2014) and also with modeling systems using MEGAN 2.1 isoprene emissions compared with ambient isoprene concentrations in Texas (Kota et al., 2015) and southern Missouri (Carlton and Baker, 2011). The airborne flux measurements of Misztal et al. (2014) are lower than the

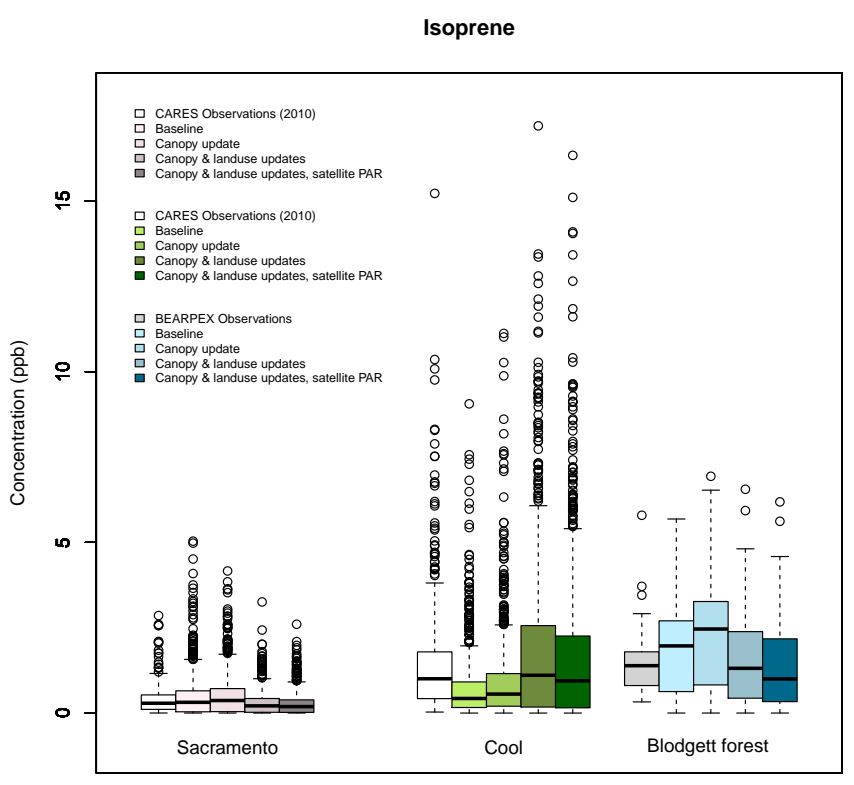

Figure 6. Distribution of observed and modeled isoprene. Observations at Sacramento and Cool represent June 2010. Observations at Blodgett Forest match the modeled period. 


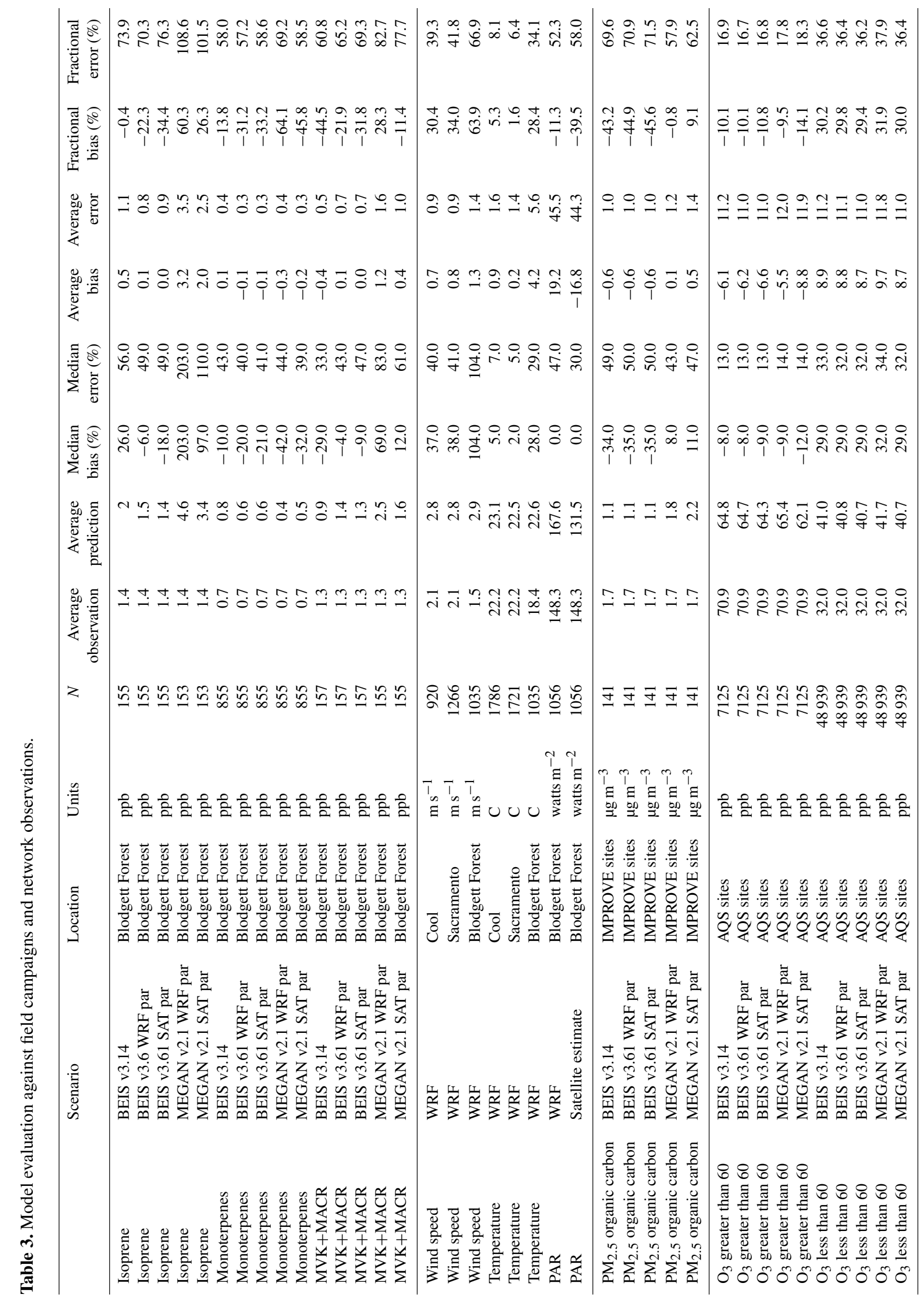




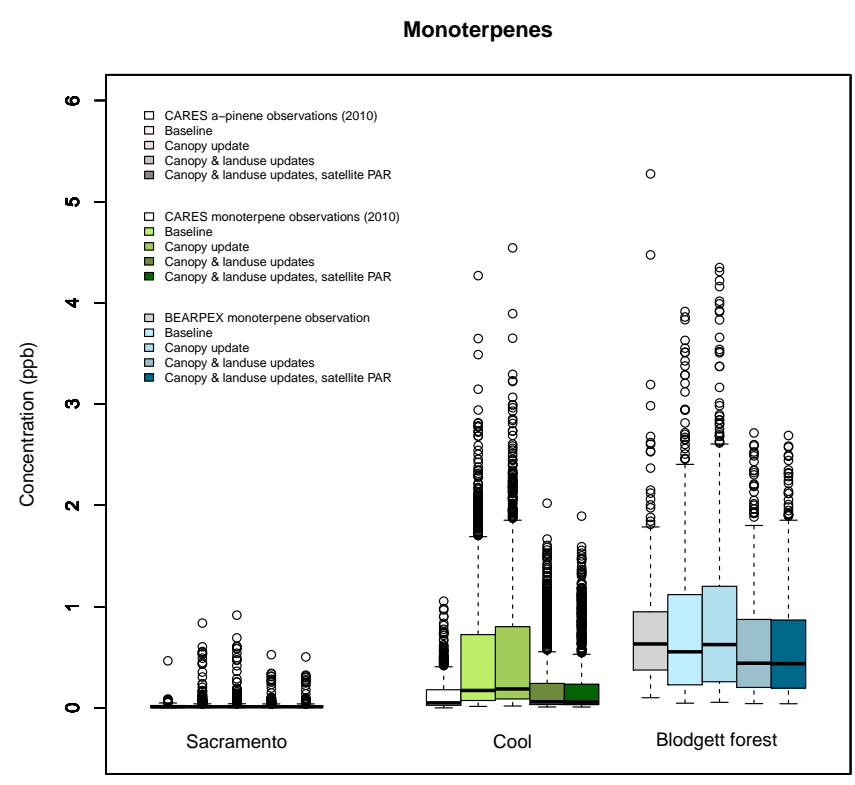

Figure 7. Distribution of observed and modeled monoterpenes. Observations at Sacramento and Cool represent June 2010. Observations at Blodgett Forest match the modeled period.

MEGAN estimates for the northern California modeling domain evaluated here and the MEGAN canopy model behaved similarly to BEIS 3.61 (Fig. 1) indicating that the MEGAN overestimate in isoprene is likely due to the MEGAN 2.1 emission factors in the modeling domain. Using the MEGAN model estimates of monoterpenes resulted in overestimates at Cool and underestimates at Blodgett Forest. Estimates of isoprene using MEGAN improved when using satellite PAR as input rather than WRF solar radiation. This is consistent with similar evaluation in other parts of the United States (Carlton and Baker, 2011). The use of satellite PAR with MEGAN exacerbated monoterpene overestimates at Cool and increased model estimates at Blodgett Forest reducing the model underestimate. First-generation oxidation products of isoprene (methacrolein and methyl vinyl ketones) were also measured at Blodgett Forest in 2009. Model performance is similar to isoprene where BEIS estimates compare favorably with measurements, and MEGAN 2.1 emissions result in notable overestimates (Fig. S7) similar to previous studies (Kota et al., 2015). Methacrolein can further react in the atmosphere to form methacryloyl peroxynitrate (MPAN) which can form methacrylic acid epoxide (MAE) and subsequently secondary organic aerosol including aerosol methylglyceric acid, organic sulfates, and organic nitrates (Worton et al., 2013). CMAQ overestimates MPAN at Blodgett Forest using either biogenic emissions model, but overestimates are greater when using MEGAN. Model performance for isoprene propagates through secondary reactions and could lead to similar over- or underestimates of SOA.

\section{Future direction}

The updated biomass and tree species vegetation characterization in BELD would benefit from additional evaluation for other parts of the conterminous United States. It is critically important to evaluate biogenic emissions models with field experiments designed for biogenic model evaluation or those that provide robust measurements of key biogenic VOC species, such as those used for this assessment. Future work is planned to evaluate BEIS against a larger field study in California designed for biogenic emissions model evaluation (2011 California Airborne BVOC Emission Research in Natural Ecosystem Transects; CABERNET) (Karl et al., 2013; Misztal et al., 2014) and also with a field study done in the southeast United States during the summer of 2013 (Southern Oxidant and Aerosol Study; SOAS). Evaluation of the model in urban areas would be useful although little field data exist for urban areas making this type of assessment difficult.

\section{Code and data availability}

BEIS 3.61 code is available upon request prior to the public release of CMAQ v5.1 and available now in SMOKE 3.6.5 (https://www.cmascenter.org/smoke/; CMAQ CTM, 2016). Please contact Jesse Bash at bash.jesse@epa.gov for more information.

WRF source code is accessible from http://www2. mmm.ucar.edu/wrf/users/download/get_source.html (Skamarock et al., 2016). NLCD land cover data are accessible from http://www.mrlc.gov/nlcd2001.php (Homer et al., 2014). MODIS land cover data are accessible from https://lpdaac.usgs.gov/dataset_discovery/modis/ modis_products_table/mcd12q1 (LP DAAC, 2014). Meteorological data for Blodgett Forest, Twichell, Viara Ranch are accessible from http://ameriflux-data.lbl.gov (Goldstein and Fares, 2016; Baldocchi et al., 2016). USDA FIA 5.1 data are accessible from http: //apps.fs.fed.us/fiadb-downloads/CSV/datamart_csv.html (O'Connell et al., 2015). The U.S. biomass map is accessible from http://data.fs.usda.gov/geodata/rastergateway/ biomass/conus_forest_biomass.php (Blackard et al., 2014). 2008 NEI Emissions Inventory data are accessible from https://www.epa.gov/air-emissions-inventories/ 2008-national-emissions-inventory-nei-data (U.S. Environmental Protection Agency, 2016).

\section{Information about the Supplement}

Additional model output, comparison with measurements, and a flowchart of land use data processing are provided in the Supplement.

The Supplement related to this article is available online at doi:10.5194/gmd-9-2191-2016-supplement. 
Acknowledgements. The authors would like to acknowledge Lara Reynolds, Charles Chang, Allan Beidler, Chris Allen, James Beidler, and Chris Geron; Alex Guenther, Jeong-Hoo Park, and Allen H. Goldstein from the University of California, Berkeley; Berk Knighton and Cody Floerchinger from the University of Montana; Gunnar Shade and Chang Hyoun from Texas A\&M University; Thomas Jobson from Washington State University; and David Simpson and Hannah Imhof from Chalmers University for a useful discussion on the canopy model. Although this work was reviewed by EPA and approved for publication, it may not necessarily reflect official Agency policy.

Edited by: G. A. Folberth

\section{References}

Almand-Hunter, B. B., Walker, J. T., Masson, N. P., Hafford, L., and Hannigan, M. P.: Development and validation of inexpensive, automated, dynamic flux chambers, Atmos. Meas. Tech., 8, 267-280, doi:10.5194/amt-8-267-2015, 2015.

Baker, K. R., Misenis, C., Obland, M. D., Ferrare, R. A., Scarino, A. J., and Kelly, J. T.: Evaluation of surface and upper air fine scale WRF meteorological modeling of the May and June 2010 CalNex period in California, Atmos. Environ., 80, 299-309, doi:10.1016/j.atmosenv.2013.08.006, 2013.

Baldocchi, D., Verfaillie, J., Sturteveant, C., Hatala, J., Koteen, L., Detto, M., and Knox, S.: Twichell Island and Viara Ranch AmeriFlux Data, available at: http://ameriflux-data.lbl.gov, last access: 16 March 2016.

Beaver, M. R., Clair, J. M. St., Paulot, F., Spencer, K. M., Crounse, J. D., LaFranchi, B. W., Min, K. E., Pusede, S. E., Wooldridge, P. J., Schade, G. W., Park, C., Cohen, R. C., and Wennberg, P. O.: Importance of biogenic precursors to the budget of organic nitrates: observations of multifunctional organic nitrates by CIMS and TD-LIF during BEARPEX 2009, Atmos. Chem. Phys., 12, 5773-5785, doi:10.5194/acp-12-5773-2012, 2012.

Bell, M. L., McDermott, A., Zeger, S. L., Samet, J. M., and Dominici, F.: Ozone and short-term mortality in 95 US urban communities, 1987-2000, JAMA - J. Am. Med. Assoc., 292, 23722378, doi:10.1001/jama.292.19.2372, 2004.

Bivand, R., Keitt, T., Rowlingson, B., Pebesma, E., Summer, M., Hijmans, R., and Rouault, E.: Package 'rgdal': Bindings for the Geosptail Data Abstraction Library, available at: http://cran. r-project.org/web/packages/rgdal/rgdal.pdf, last access: $8 \mathrm{Au}-$ gust 2014.

Blackard, J., Finco, M., Helmer, E., Holden, G., Hoppus, M., Jacobs, D., Lister, A., Moisen, G., Nelson, M., and Riemann, R.: Mapping US forest biomass using nationwide forest inventory data and moderate resolution information, Remote Sens. Environ., 112, 1658-1677, 2008.

Blackard, J. A., Finco, M. V., Helmer, E. H., Holden, G. R., Hoppus, M. L., Jacobs, D. M., Lister, A. J., Moisen, G. G., Nelson, M. D., Riemann, R., Ruefenacht, B., Salajanu, D., Weyermann, D. L., Winterberger, K. C., Brandeis, T. J., Czaplewski, R. L., McRoberts, R. E., Patterson, P. L., and Tymcio, R. P.: U.S. Biomass Map, available at: http://data.fs.usda.gov/geodata/ rastergateway/biomass/conus_forest_biomass.php, last access: 14 August 2014.
Byun, D. and Schere, K. L.: Review of the governing equations, computational algorithms, and other components of the models3 Community Multiscale Air Quality (CMAQ) modeling system, Appl. Mech. Rev., 59, 51-77, doi:10.1115/1.2128636, 2006.

Campbell, G. S. and Norman, J. M.: An introduction to environmental biophysics, Springer, New York, USA, 1998.

Carlton, A. G. and Baker, K. R.: Photochemical Modeling of the Ozark Isoprene Volcano: MEGAN, BEIS, and Their Impacts on Air Quality Predictions, Environ. Sci. Technol., 45, 4438-4445, doi:10.1021/es200050x, 2011.

Carlton, A. G., Turpin, B. J., Altieri, K. E., Seitzinger, S. P., Mathur, R., Roselle, S. J., and Weber, R. J.: CMAQ model performance enhanced when in-cloud SOA is included: comparisons of OC predictions with measurements, Environ. Sci. Technol., 42, 8798-8802, 2008.

Carlton, A. G., Wiedinmyer, C., and Kroll, J. H.: A review of Secondary Organic Aerosol (SOA) formation from isoprene, Atmos. Chem. Phys., 9, 4987-5005, doi:10.5194/acp-9-4987-2009, 2009.

Carlton, A. G., Bhave, P. V., Napelenok, S. L., Edney, E. O., Sarwar, G., Pinder, R. W., Pouliot, G. A., and Houyoux, M.: Treatment of secondary organic aerosol in CMAQv4.7, Environ. Sci. Technol., 44, 8553-8560, 2010.

Chameides, W. L., Lindsay, R. W., Richardson, J., and Kiang, C. S.: The role of biogenic huydrocarbons in urban photochemical smog - Atlanta as a case-study, Science, 241, 1473-1475, 1988.

Chojnacky, D. C., Heath, L. S., and Jenkins, J. C.: Updated generalized biomass equations for North American tree species, Forestry, 87, 129-151, 2014.

CMAQ CTM: BEIS 3.61 Code, available at: https://www. cmascenter.org/smoke/, last access: 3 June 2016.

Critchfield, W. B. and Little, E. L.: Geographic distribution of the pines of the world, US Department of Agriculture, Forest Service, Washington D.C., USA, 1966.

Davis, F. W., Stoms, D. M., Hollander, A. D., Thomas, K. A., Stine, P. A., Odion, D., Borchert, M. I., Thorne, J. H., Gray, M. V., Walker, R. E., Warner, K., and Graae, J.: The California Gap Analysis Project - Final Report, University of California, Santa Barbara, CA, USA, 1998.

Dreyfus, G. B., Schade, G. W., and Goldstein, A. H.: Observational constraints on the contribution of isoprene oxidation to ozone production on the western slope of the Sierra Nevada, California, J. Geophys. Res.-Atmos., 107, ACH 1-1-ACH 1-17, 2002.

Fann, N., Fulcher, C. M., and Baker, K.: The Recent and Future Health Burden of Air Pollution Apportioned Across US Sectors, Environ. Sci. Technol., 47, 3580-3589, 2013.

FLUXNET: Duke Fores Open Field, available at: http://fluxnet.ornl. gov/site/867, last access: 8 August 2014.

Foley, K. M., Roselle, S. J., Appel, K. W., Bhave, P. V., Pleim, J. E., Otte, T. L., Mathur, R., Sarwar, G., Young, J. O., Gilliam, R. C., Nolte, C. G., Kelly, J. T., Gilliland, A. B., and Bash, J. O.: Incremental testing of the Community Multiscale Air Quality (CMAQ) modeling system version 4.7, Geosci. Model Dev., 3, 205-226, doi:10.5194/gmd-3-205-2010, 2010.

Fountoukis, C. and Nenes, A.: ISORROPIA II: a computationally efficient thermodynamic equilibrium model for $\mathrm{K}^{+}-$ $\mathrm{Ca}^{2+}-\mathrm{Mg}^{2+}-\mathrm{NH}_{4}^{+}-\mathrm{Na}^{+}-\mathrm{SO}_{4}^{2-}-\mathrm{NO}_{3}^{-}-\mathrm{Cl}^{-}-\mathrm{H}_{2} \mathrm{O}$ aerosols, Atmos. Chem. Phys., 7, 4639-4659, doi:10.5194/acp-7-4639-2007, 2007. 
Goldstein, A. and Fares, S.: Blodgett Forest AmeriFlux Data, available at: http://ameriflux-data.lbl.gov, last access: 16 March 2016.

Guenther, A., Karl, T., Harley, P., Wiedinmyer, C., Palmer, P. I., and Geron, C.: Estimates of global terrestrial isoprene emissions using MEGAN (Model of Emissions of Gases and Aerosols from Nature), Atmos. Chem. Phys., 6, 3181-3210, doi:10.5194/acp-63181-2006, 2006.

Guenther, A., Duhl, T., Sakulyanontvittaya, T., and Wang, X.: MEGAN version 2.10 User's Guide, available at: http://lar.wsu. edu/megan/guides.html, last access: 25 August 2014.

Guenther, A. B., Zimmerman, P. R., Harley, P. C., Monson, R. K., and Fall, R.: Isoprene and monoterpene emission rate variability: Model evaluations and sensitivity analyses, J. Geophys. Res.Atmos., 97, 12609-12617, doi:10.1029/93JD00527, 1993.

Guenther, A. B., Jiang, X., Heald, C. L., Sakulyanontvittaya, T., Duhl, T., Emmons, L. K., and Wang, X.: The Model of Emissions of Gases and Aerosols from Nature version 2.1 (MEGAN2.1): an extended and updated framework for modeling biogenic emissions, Geosci. Model Dev., 5, 1471-1492, doi:10.5194/gmd-51471-2012, 2012.

Henderson, B. H., Akhtar, F., Pye, H. O. T., Napelenok, S. L., and Hutzell, W. T.: A database and tool for boundary conditions for regional air quality modeling: description and evaluation, Geosci. Model Dev., 7, 339-360, doi:10.5194/gmd-7-3392014, 2014.

Homer, C., Huang, C., Yang, L., Wylie, B. K., and Coan, M.: Development of a 2001 national land-cover database for the United States, Photogramm. Eng. Rem. S., 70, 829-840, 2004.

Homer, C., Dewitz, J., Fry, J., Coan, M., Hossain, N., Larson, C., Herold, N., McKerrow, A., VanDriel, J. N., and Wickham, J.: NLCD Land Cover, available at: http://www.mrlc.gov/nlcd2001. php, last access: 6 May 2014

Hutzell, W. T., Luecken, D. J., Appel, K. W., and Carter, W. P. L.: Interpreting predictions from the SAPRC07 mechanism based on regional and continental simulations, Atmos. Environ., 46, 417429, doi:10.1016/j.atmosenv.2011.09.030, 2012

Jenkins, J. C., Chojnacky, D. C., Heath, L. S., and Birdsey, R. A.: National-scale biomass estimators for United States tree species, Forest Sci., 49, 12-35, 2003.

Karl, T., Misztal, P., Jonsson, H., Shertz, S., Goldstein, A., and Guenther, A.: Airborne Flux Measurements of BVOCs above Californian Oak Forests: Experimental Investigation of Surface and Entrainment Fluxes, OH Densities, and Damköhler Numbers, J. Atmos. Sci., 70, 3277-3287, 2013.

Kelly, J. T., Baker, K. R., Nowak, J. B., Murphy, J. G., Markovic, M. Z., VandenBoer, T. C., Ellis, R. A., Neuman, J. A., Weber, R. J., and Roberts, J. M.: Fine-scale simulation of ammonium and nitrate over the South Coast Air Basin and San Joaquin Valley of California during CalNex-2010, J. Geophys. Res.-Atmos., 119, 3600-3614, 2014.

Kinnee, E., Geron, C., and Pierce, T.: United States land use inventory for estimating biogenic ozone precursor emissions, Ecol. Appl., 7, 46-58, 1997.

Kota, S. H., Schade, G., Estes, M., Boyer, D., and Ying, Q.: Evaluation of MEGAN predicted biogenic isoprene emissions at urban locations in Southeast Texas, Atmos. Environ., 110, 54-64, doi:10.1016/j.atmosenv.2015.03.027, 2015.
Kwok, R., Napelenok, S., and Baker, K.: Implementation and evaluation of $\mathrm{PM}_{2.5}$ source contribution analysis in a photochemical model, Atmos. Environ., 80, 398-407, 2013.

Land Processes Distributed Active Archive Center (LP DAAC): MODIS Land Cover, 2006 MODIS Combined MCD12Q1 Land Use Data, U.S. Geological Survey (USGS) Center for Earth Resources Observation and Science (EROS), the data product for the image was provided by NASA, avialable at: https://lpdaac.usgs.gov/dataset_discovery/modis/modis_ products_table/mcd12q1, last access: 22 May 2014.

Lefohn, A. S., Emery, C., Shadwick, D., Wernli, H., Jung, J., and Oltmans, S. J.: Estimates of background surface ozone concentrations in the United States based on modelderived source apportionment, Atmos. Environ., 84, 275-288, doi:10.1016/j.atmosenv.2013.11.033, 2014.

Little Jr., E. L.: Atlas of United States trees, Volume 1, Conifers and important hardwoods. Miscellaneous publication 1146, US Department of Agriculture, Forest Service, Washington, DC, USA, 1971.

Little Jr., E. L.: Atlas of United States trees, Volume 3, Minor wesern hardwood. Miscellaneous publication 1314, US Department of Agriculture, Forest Service, Washington, DC, USA, 1976.

Misztal, P. K., Karl, T., Weber, R., Jonsson, H. H., Guenther, A. B., and Goldstein, A. H.: Airborne flux measurements of biogenic isoprene over California, Atmos. Chem. Phys., 14, 1063110647, doi:10.5194/acp-14-10631-2014, 2014.

Monteith, J. and Unsworth, M.: Principles of Environmental Physics: Plants, Animals, and the Atmosphere, Academic Press, Oxford, UK, 2013.

Niinemets, Ü., Arneth, A., Kuhn, U., Monson, R. K., Peñuelas, J., and Staudt, M.: The emission factor of volatile isoprenoids: stress, acclimation, and developmental responses, Biogeosciences, 7, 2203-2223, doi:10.5194/bg-7-2203-2010, 2010.

Nowak, D. J. and Greenfield, E. J.: Tree and impervious cover in the United States, Landscape Urban Plan., 107, 21-30, 2012.

O'Connell, B., LaPoint, E., Turner, J., Ridley, T., Boyer, D., Wilson, A., Waddell, K., and Conkling, B.: The Forest Inventory and Analysis Database: Database Description and Users Manual Version 5.1. 2 for Phase 2, USDA Forest Service, available at: http://www.fia.fs.fed.us/library/database-documentation/ (last access: 18 July 2015), 2012.

O'Connell, B., LaPoint, E., Turner, J., Ridley, T., Boyer, D., Wilson, A., Waddell, K., and Conkling, B.: USDA FIA data, available at: http://apps.fs.fed.us/fiadb-downloads/CSV/ datamart_csv.html, last access: 18 July 2015.

Park, C., Schade, G. W., and Boedeker, I.: Flux measurements of volatile organic compounds by the relaxed eddy accumulation method combined with a GC-FID system in urban Houston, Texas, Atmos. Environ., 44, 2605-2614, 2010.

Park, C., Schade, G. W., and Boedeker, I.: Characteristics of the flux of isoprene and its oxidation products in an urban area, J. Geophys. Res.-Atmos., 116, D21303, doi:10.1029/2011JD015856, 2011.

Pierce, T. E. and Waldruff, P. S.: PC-BEIS: A personal computer version of the biogenic emissions inventory system, J. Air Waste Manage., 41, 937-941, 1991.

Pinker, R. T. and Laszlo, I.: Global Distribution of Photosynthetically Active Radiation as Observed from Satellites, J. Climate, 5, 56-65, 1992. 
Pinker, R. T., Laszlo, I., Tarpley, J. D., and Mitchell, K.: Geostationary satellite parameters for surface energy balance, Earth's Atmosphere, Ocean Surface Studies, 30, 2427-2432, 2002.

Pope, C. A. and Dockery, D. W.: Health effects of fine particulate air pollution: Lines that connect, J. Air Waste Manage., 56, 709742, 2006.

Pope III, C. A., Muhlestein, J. B., May, H. T., Renlund, D. G., Anderson, J. L., and Horne, B. D.: Ischemic heart disease events triggered by short-term exposure to fine particulate air pollution, Circulation, 114, 2443-2448, doi:10.1161/circulationaha.106.636977, 2006.

Sakulyanontvittaya, T., Duhl, T., Wiedinmyer, C., Helmig, D., Matsunaga, S., Potosnak, M., Milford, J., and Guenther, A.: Monoterpene and sesquiterpene emission estimates for the United States, Environ. Sci. Technol., 42, 1623-1629, 2008.

Sarwar, G., Fahey, K., Kwok, R., Gilliam, R. C., Roselle, S. J., Mathur, R., Xue, J., Yu, J., and Carter, W. P. L.: Potential impacts of two $\mathrm{SO}_{2}$ oxidation pathways on regional sulfate concentrations: Aqueous-phase oxidation by $\mathrm{NO}_{2}$ and gas-phase oxidation by Stabilized Criegee Intermediates, Atmos. Environ., 68, 186-197, doi:10.1016/j.atmosenv.2012.11.036, 2013.

Schwede, D., Pouliot, G., and Pierce, T.: Changes to the Biogenic Emissions Inventory System Version 3 (BEIS3), in: Proceedings of the 4th CMAS Models-3 Users' Conference, Chapel Hill, NC, USA, 26-28 September 2005, available at: https://www. cmascenter.org/conference/2005/abstracts/2_7.pdf (last access: 31 May 2016), 2005.

Simon, H., Baker, K. R., and Phillips, S.: Compilation and interpretation of photochemical model performance statistics published between 2006 and 2012, Atmos. Environ., 61, 124-139, 2012.

Simon, H., Baker, K. R., Akhtar, F., Napelenok, S. L., Possiel, N., Wells, B., and Timin, B.: A Direct sensitivity approach to predict hourly ozone resulting from compliance with the National Ambient Air Quality Standard, Environ. Sci. Technol., 47, 2304-2313, 2013.

Skamarock, W. C., Klemp, J. B., Dudhia, J., Gill, D. O., Barker, D. M., Duda, M. G., Huang, X., Wang, W., and Powers, J. G.: A description of the Advanced Reserch WRF version 3., NCAR Technical Note NCAR/TN-475+STR, doi:10.1175/MWR-D12-00042.1, 2008.

Skamarock, W. C., Klemp, J. B., Dudhia, J., Gill, D. O., Barker, D. M., Duda, M. G., Huang, X., Wang, W., and Powers, J. G.: WRF model, available at: http://www2.mmm.ucar.edu/wrf/ users/download/get_source.html, last access: 3 June 2016.

US Environmental Protection Agency: Regulatory Impact Analysis for the Proposed Federal Transport Rule, Docket ID No. EPAHQ-OAR-2009-0491, available at: http://www.epa.gov/ttn/ecas/ regdata/RIAs/proposaltrria_final.pdf (last access: 12 December 2014), 2010.

US Environmental Protection Agency: Air Quality Modeling Technical Support Document: Heavy-Duty Vehicle Greenhouse Gas Emission Standards Final Rule, EPA-454/R-11-004, Research Triangle Park, North Carolina, USA, 2011.

US Environmental Protection Agency: Air Quality Modeling Technical Support Document for the Regulatory Impact Analysis for the Revisions to the National Ambient Air Quality Standards for Particulate Matter, Office of Air Quality Planning and Standards, Research Triangle Park, North Carolina, USA, 2012.
US Environmental Protection Agency: 2008 National Emissions Inventory (NEI), Office of Air Quality Planning and Standards Air Quality Assessment Division Emissions Inventory and Analysis Group Research Triangle Park, North Carolina, available at: https:/www.epa.gov/air-emissions-inventories/ 2008-national-emissions-inventory-nei-data, last access: 3 June 2016.

Warneke, C., de Gouw, J. A., Del Negro, L., Brioude, J., McKeen, S., Stark, H., Kuster, W. C., Goldan, P. D., Trainer, M., Fehsenfeld, F. C., Wiedinmyer, C., Guenther, A. B., Hansel, A., Wisthaler, A., Atlas, E., Holloway, J. S., Ryerson, T. B., Peischl, J., Huey, L. G., and Hanks, A. T. C.: Biogenic emission measurement and inventories determination of biogenic emissions in the eastern United States and Texas and comparison with biogenic emission inventories, J. Geophys. Res.-Atmos., 115, D00F18, doi:10.1029/2009jd012445, 2010.

Weiss, A. and Norman, J.: Partitioning solar radiation into direct and diffuse, visible and near-infrared components, Agr. Forest Meteorol., 34, 205-213, 1985.

Wiedinmyer, C., Greenberg, J., Guenther, A., Hopkins, B., Baker, K., Geron, C., Palmer, P. I., Long, B. P., Turner, J. R., Petron, G., Harley, P., Pierce, T. E., Lamb, B., Westberg, H., Baugh, W., Koerber, M., and Janssen, M.: Ozarks Isoprene Experiment (OZIE): Measurements and modeling of the "isoprene volcano", J. Geophys. Res.-Atmos., 110, D18307, doi:10.1029/2005jd005800, 2005.

Worton, D. R., Surratt, J. D., LaFranchi, B. W., Chan, A. W. H., Zhao, Y., Weber, R. J., Park, J.-H., Gilman, J. B., de Gouw, J., Park, C., Schade, G., Beaver, M., Clair, J. M. S., Crounse, J., Wennberg, P., Wolfe, G. M., Harrold, S., Thornton, J. A., Farmer, D. K., Docherty, K. S., Cubison, M. J., Jimenez, J.-L., Frossard, A. A., Russell, L. M., Kristensen, K., Glasius, M., Mao, J., Ren, X., Brune, W., Browne, E. C., Pusede, S. E., Cohen, R. C., Seinfeld, J. H., and Goldstein, A. H.: Observational Insights into Aerosol Formation from Isoprene, Environ. Sci. Technol., 47, 11403-11413, doi:10.1021/es4011064, 2013.

Zaveri, R. A., Shaw, W. J., Cziczo, D. J., Schmid, B., Ferrare, R. A., Alexander, M. L., Alexandrov, M., Alvarez, R. J., Arnott, W. P., Atkinson, D. B., Baidar, S., Banta, R. M., Barnard, J. C., Beranek, J., Berg, L. K., Brechtel, F., Brewer, W. A., Cahill, J. F., Cairns, B., Cappa, C. D., Chand, D., China, S., Comstock, J. M., Dubey, M. K., Easter, R. C., Erickson, M. H., Fast, J. D., Floerchinger, C., Flowers, B. A., Fortner, E., Gaffney, J. S., Gilles, M. K., Gorkowski, K., Gustafson, W. I., Gyawali, M., Hair, J., Hardesty, R. M., Harworth, J. W., Herndon, S., Hiranuma, N., Hostetler, C., Hubbe, J. M., Jayne, J. T., Jeong, H., Jobson, B. T., Kassianov, E. I., Kleinman, L. I., Kluzek, C., Knighton, B., Kolesar, K. R., Kuang, C., Kubátová, A., Langford, A. O., Laskin, A., Laulainen, N., Marchbanks, R. D., Mazzoleni, C., Mei, F., Moffet, R. C., Nelson, D., Obland, M. D., Oetjen, H., Onasch, T. B., Ortega, I., Ottaviani, M., Pekour, M., Prather, K. A., Radney, J. G., Rogers, R. R., Sandberg, S. P., Sedlacek, A., Senff, C. J., Senum, G., Setyan, A., Shilling, J. E., Shrivastava, M., Song, C., Springston, S. R., Subramanian, R., Suski, K., Tomlinson, J., Volkamer, R., Wallace, H. W., Wang, J., Weickmann, A. M., Worsnop, D. R., Yu, X.-Y., Zelenyuk, A., and Zhang, Q.: Overview of the 2010 Carbonaceous Aerosols and Radiative Effects Study (CARES), Atmos. Chem. Phys., 12, 7647-7687, doi:10.5194/acp-12-7647-2012, 2012. 